Abraham Thomas ${ }^{1}$

\title{
Processing and Analysis of ASTER and Landsat 8 Scenes to Aid in Geological Mapping: A Case Study of Murchison Greenstone Belt Area, South Africa
}

\begin{abstract}
This paper presents processing and analysis results of ASTER and Landsat 8 scenes to aid in geological mapping of Murchison Greenstone Belt region of Limpopo Province, South Africa. Images of ASTER acquired in 2005 and 2006 and Landsat 8 acquired in 2019 were downloaded and subset covering 5 mapping sheets was extracted. Images of different band ratios and band combinations were experimented using ENVI and SNAP software to identify suitable band/band ratio combinations to produce FCCs that enabled discrimination of lithology, structural features, lineaments, alteration and iron oxides, land/ water, surface features, vegetation cover and healthy vegetation etc. Using DEM data, slope and shaded relief were also prepared that enabled the identification of the extent of protruded outcrops, some structural features and lineaments using different FCC displays. These datasets prepared in ENVI file format were later exported to GeoTiff/Imagine file for display in ArcMap by the mapping geologists. FCCs made in various band combinations, ratio combination and also with slope are useful in discriminating geology, structural features and protruded outcrops including dykes that are not so visible in a true colour image of the same resolution. This study could illustrate the usefulness of remote sensing analysis to aid in geological mapping using freely available ASTER and Landsat 8 data.
\end{abstract}

Keywords: $\quad$ ASTER, Landsat 8, Murchison Greenstone Belt, geological mapping

Received: 22 January 2020; accepted: 20 April 2020

(C) 2020 Author. This is an open access publication, which can be used, distributed and reproduced in any medium according to the Creative Commons CC-BY 4.0 License.

1 Geophysics and Remote Sensing Unit, Council for Geoscience, Pretoria, South Africa, email: athomas@ geoscience.org.za; athomas1965@gmail.com

ORCID ID: https://orcid.org/0000-0003-4412-3152 


\section{Introduction}

Freely available remote sensing datasets made available through optical satellites such as Advanced Spaceborne Thermal Emission and Reflection (ASTER) radiometer, Landsat Thematic Mapper (TM) and Sentinel-2 are being widely used in geological remote sensing as they aid in discriminating lithological boundaries and geological features, structural features/lineaments and mineral alteration zones. There are many case studies [1-3] illustrating the application of multispectral data (such as ASTER and Landsat TM data) in geological mapping that allow discrimination of lithological units, structural interpretation and detection of minerals bearing host rocks. Many researchers have made use of ASTER, Landsat TM and Landsat 8 data for geological mapping, visualising lineaments, and mineral prospecting [4-10].

Standard image analysis techniques of displaying image bands in false colour composites (FCC) and band ratios have been extensively used in remote sensing applications for various purposes including the extraction of geological information. Band ratios are derived by using different combinations of spectral bands that can be added, subtracted, multiplied and divided using image algebra. The result of the image algebra is another image with information that can be indicative of specific characteristics such as a highlighted specific surface feature of land cover or rock types or mineral occurrence that will be useful for the generation of geological map with lithological units. Band ratioing and displaying of the different bands and ratio images in false colour composites with different image enhancement tools (such as linear, equalisation stretching etc.) allows for discrimination of land surface features including, water, vegetation types, rock outcrops, structural features (lineaments), lithological boundaries and rock types.

The ASTER instrument operating aboard NASA's Terra spacecraft was launched in late 1999 and is still in operation; however, its short-wave infrared channels stopped operations in April 2008, due to the failure of the cryocooler [11]. Though ASTER optical data was used extensively for geological mapping purposes, the data was not freely available after its launch. One scene of ASTER optical data cost about US $\$ 55$ as a commercial data product [12]. In 2009, the altimetric data from the ASTER instrument were made available to the public. Beginning 1st April 2016, all Earth imagery from the Japanese remote sensing instrument ASTER operating aboard NASA's Terra spacecraft was made available to users everywhere at no cost [13]. However, the number of cloud free archived scenes prior to April 2008 were limited when the area of interest of this study was searched for. As geological features do not vary much in a timespan of one or two decades, the mapping geologists feel that older high-resolution satellite data like ASTER can still be used for geological mapping purposes.

The primary objective of this study was to make use of freely available high-resolution ASTER data and medium resolution Landsat 8 data to aid in geological mapping of the Murchison Greenstone Belt (MGB) area of South Africa by generating 
suitable products or datasets using different remote sensing data processing and analysis techniques. The main data sets produced in such studies assisting geological mapping include band ratios and colour composites suitable for discriminating geology/lithology, structural features and lineaments, alteration and iron oxides, land/ water, surface features, vegetation cover and healthy vegetation, and shaded relief generated from the 1 Arc ASTER Global DEM (GDEM). This paper shows the results of different remote sensing processing and analysis conducted in ENVI, ArcGIS and SNAP software using different datasets produced from ASTER and Landsat 8 scenes covering Murchison Greenstone Belt area and their usefulness to aid in geological mapping on 1:50,000 scale.

\section{Study Area}

The study area covered the Murchison Greenstone Belt (MGB) region of Limpopo Province of South Africa (Fig. 1). The MGB is located in the north-eastern Kaapvaal Craton of South Africa.

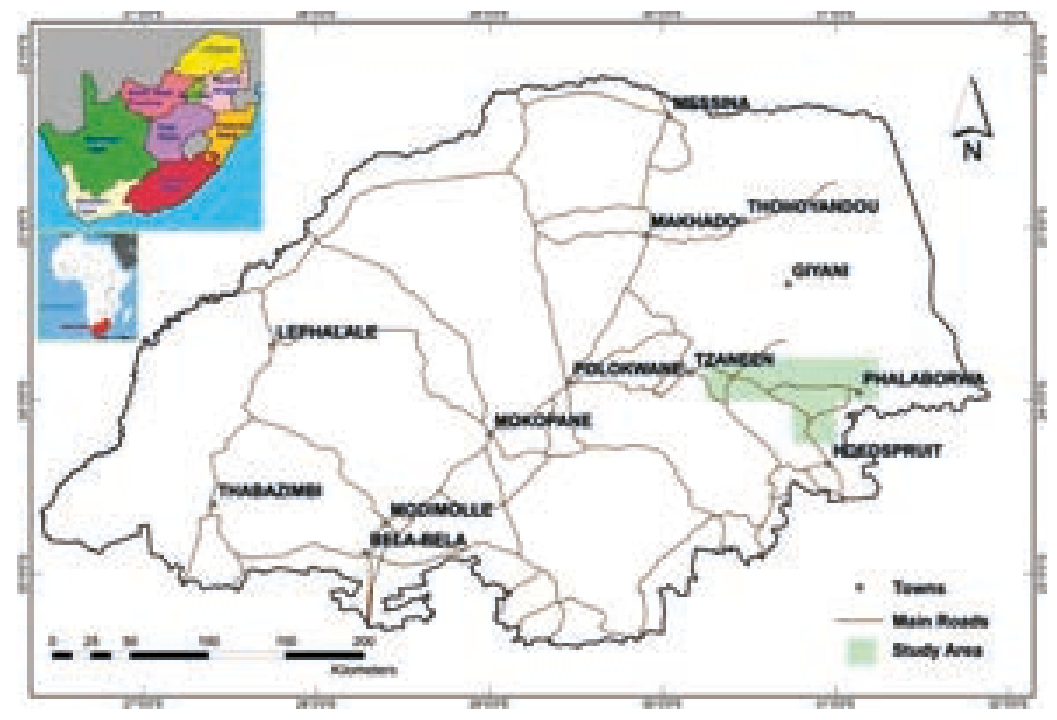

Fig. 1. Map showing the location and extent of five mapping sheets (1:50,000 scale) of Murchison Greenstone Belt area within the Limpopo Province of South Africa

The area contains Meso-Archaren metavolcanics and metasediments and is surrounded by gneisses and Granitoids. Geologically, this area is characterised by a region of Groot Letaba Gneiss (weakly to well foliated, migmatitic tonalite and trondhjemite), Novengilla Gabro Suit (metagabbro), metadiorite, quartz-feldspar porphyry, quartz-mica schist, Gravelotte Group (mafic and ultramafic volcanic rocks, chlorite 
schist, quartzite, gritstone, porphyritic tuff, banded iron-formation, arkosic quartzite, subgreywacke, siltstone, shale, minor conglomerate), Lekkersmaak Granite (grey, medium-grained [porphyritic in places], granodioritic biotite-muscovite granite), Leydsdorp Formation (mafic metavolcanic rocks [tholeiitic] with interbedded banded iron-formation, quartz-chlorite schist and quartz porphyry), Mashishimale Suite (fine- and coarse-grained biotite-hornblende monzogranite) and Phalaborwa Complex (micaceous pyroxenite, phlogopite-pyroxene and olivine-phlogopite pegmatoid, feldspathic pyroxenite, phoscorite, carbonatite, glimmerite, syenite, granite) (Fig. 2).

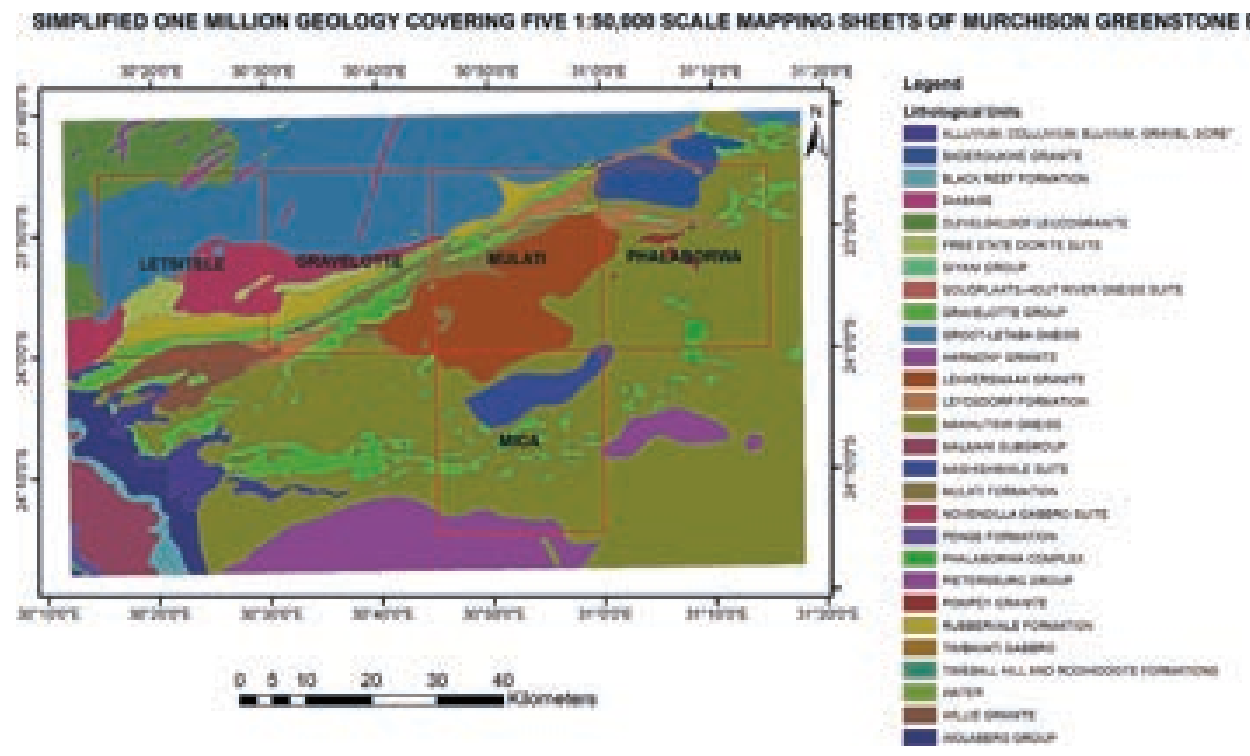

Fig. 2. Map showing the simplified geology of Murchison Greenstone Belt area (extracted from one million geological map)

\section{Data and Software Used for Remote Sensing Analysis}

The satellite data used in this study comprised 6 ASTER satellite image (AST_07XT) scenes/granules having 9 image bands (spanning from the Visible and Near Infra-Red (VNIR), Short Wave Infrared (SWIR) spectral range having resolutions of $15 \mathrm{~m}$ and $30 \mathrm{~m}$ respectively) and two scenes of 'Landsat 8 OLI/TIRS C1 Level-1 RT' - Real Time Terrain Corrected dataset containing both OLI \& TIRS bands, acquired on 19 Aug 2019 and having 11 bands with spatial resolutions of $30 \mathrm{~m}$ (VNIR \& SWIR), $15 \mathrm{~m}$ (panchromatic band known as PAN) and $100 \mathrm{~m}$ thermal infrared (TIR) bands. The dates of acquisitions of ASTER data were of 5 Sep 2005, 21 Sep 2005 and 29 Jun 2006 (the winter period having less vegetation cover). Because the ASTER SWIR data acquired from late April 2008 to the present 
exhibit anomalous saturation of values and anomalous striping, the good cloud free data available for the area of study and that could be used were of the above dates. The geographic dimensions of one ASTER scene/granule is $\sim 60 \mathrm{~km} \times 60 \mathrm{~km}$ whereas one Landsat 8 scene covers an area of about $170 \mathrm{~km}$ north-south by $183 \mathrm{~km}$ east-west [14].

Other datasets used in this study are the freely available 1 Arc ASTER Global DEM (GDEM), having $30 \mathrm{~m}$ resolution for preparing slope \& shaded relief, and One Million Geological map (Fig. 2) of South Africa (2019 edition). Note: Four tiles of ASTER GDEM data were mosaicked first using PCI Geomatica Mosaic Tool and later it was subsetted with a rectangular polygon that covered area of interest covering five mapping sheets. The software used in this study are ENVI, PCI Geomatica, ArcGIS and SNAP. SNAP stands for "SeNtinels Application Platform" and is a fully free and open-source toolbox platform that supports processing of raster imagery from ESA, Copernicus Sentinel 1/2/3, and many third-party satellite missions [15]. SNAP is a common architecture for all Sentinel Toolboxes that is being jointly developed by Brockmann Consult, Array Systems Computing and C-S [16].

\section{Methodology and Data Processing Techniques Used and Results Obtained}

\section{Product Type of ASTER and Landsat 8 Data Downloaded}

The ASTER data used is Level 2 Surface Reflectance VNIR and Crosstalk Corrected SWIR V003 known as AST_07XT Version 003 [17]. AST_07XT is a multi-file product that contains atmospherically corrected data for both the VNIR and SWIR sensors [18]. As ASTER data used is Level 2 surface reflectance, no pre-processing for geometric correction and atmospheric correction was required. The Landsat 8 data used is of 'Landsat 8 OLI/TIRS C1 Level-1 RT' - Real Time Terrain Corrected dataset containing both OLI \& TIRS bands. This dataset was processed for atmospheric correction and surface reflectance retrieval using a processing request sent through EarthExplorer the USGS online facility available for atmospheric correction (https://earthexplorer.usgs.gov/) and thus the Scene-based Surface Reflectance data (on-demand) was downloaded later.

\section{Initial Data Processing Using ENVI and ArcGIS Software and Results}

The downloaded ASTER VNIR and SWIR datasets were opened in ENVI software and the first processing step did was for making a fairly good mosaic of it with all the bands that covered area of interest (covering 8 mapping sheets on 1:50,000 scale). Each VNIR band in two adjacent ASTER scenes of the same path were first mosaicked in ENVI software using the 'Seamless Mosaic' tool. The mosaicked SWIR bands were resized to $15 \mathrm{~m}$ pixel size in ENVI using the 'Resize Data' 
tool. The VNIR and SWIR bands of a particular scene were stacked separately using the 'Layer Stacking' tool. Later a polygon covering the extent of 8 mapping sheets were prepared in ArcMap and overlaid with the extent of mosaicked bands (Fig. 3).

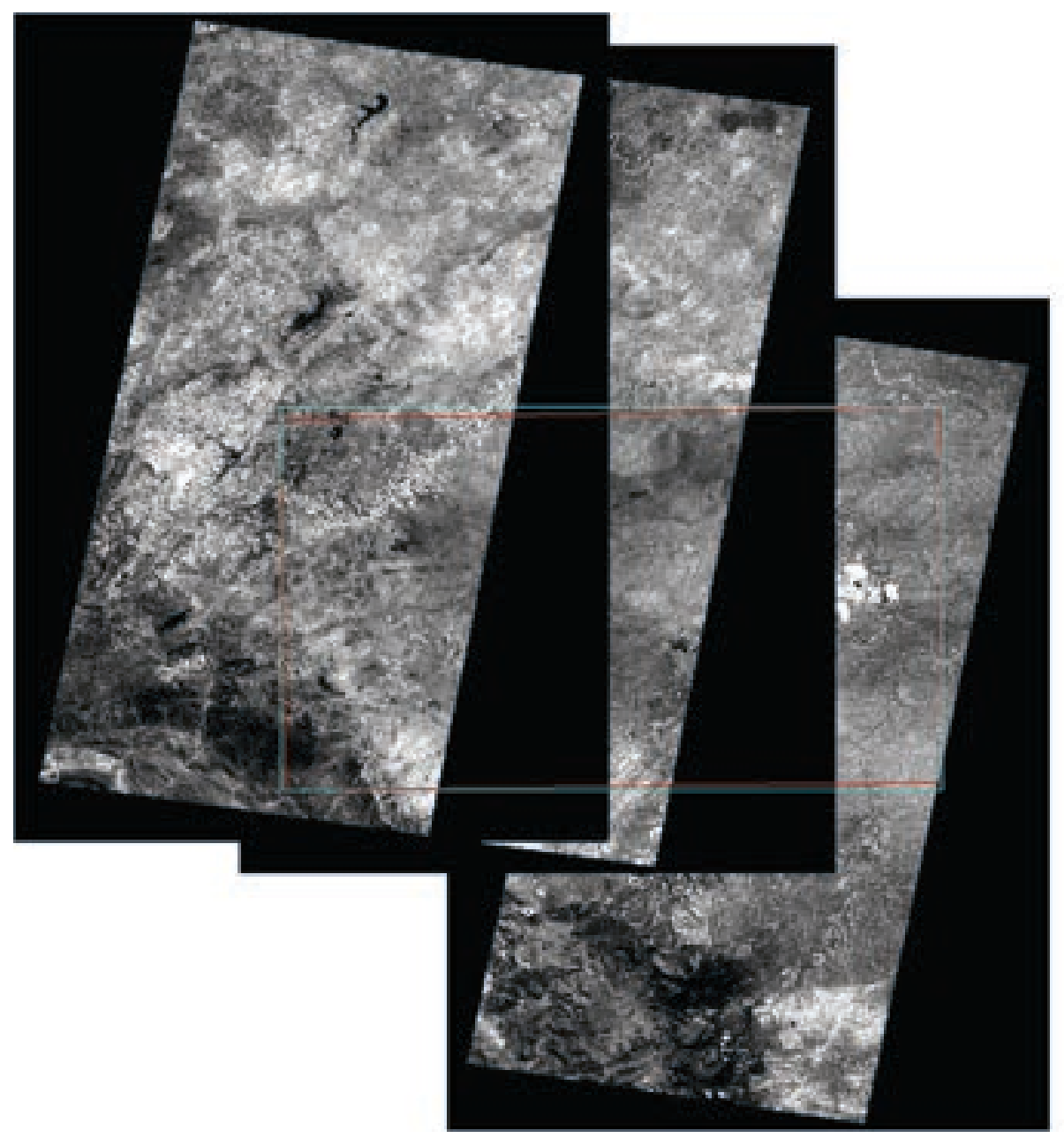

Fig. 3. Mosaics of ASTER VNIR band of adjacent scenes in the orbit direction (acquired on 5 Sep 2005, 21 Sep 2005 and 29 Jun 2006) overlaid with a polygon covering the extent of 8 mapping sheets

The area of interest covered in each mosaicked stack were digitised in ArcMap as polygons (Fig. 4) and the corresponding stacks were subsetted in ArcMap using the Clip tool (Fig. 5). Later, all stacked subsets made from clipping were mosaicked in ENVI using the Seamless Mosaic tool and this mosaic with all the bands was subsetted again using the polygon shapefile showing the extent of 8 mapping sheets. 


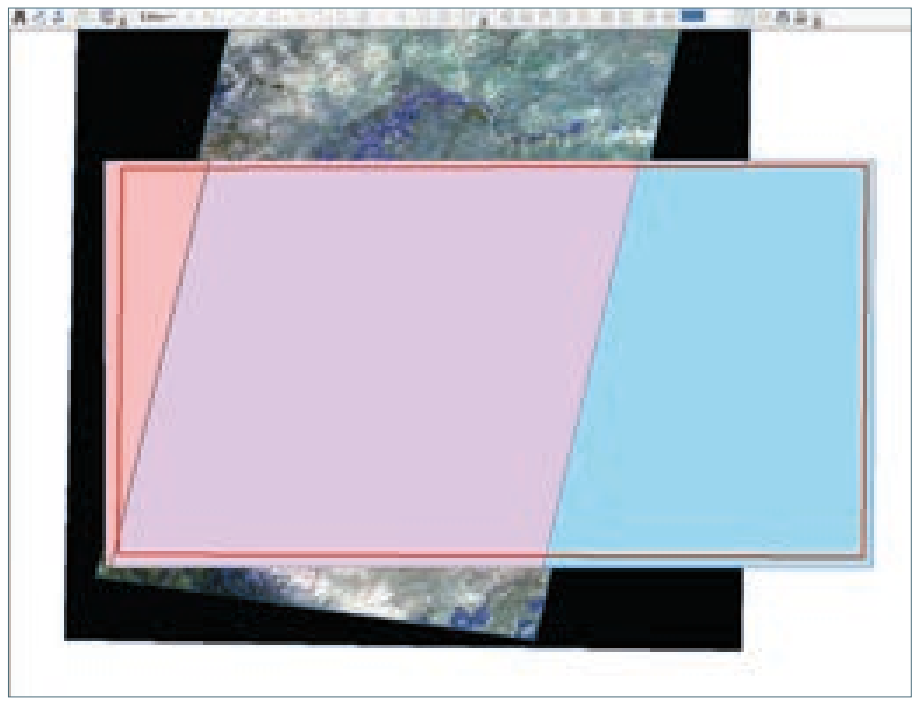

Fig. 4. Subset polygons digitised for mosaicking different ASTER scene stacks overlaid with a stack of mosaicked SWIR bands of two adjacent scenes (scenes IDs: 25492 \& 25491 acquired on 21 Sep 2005)

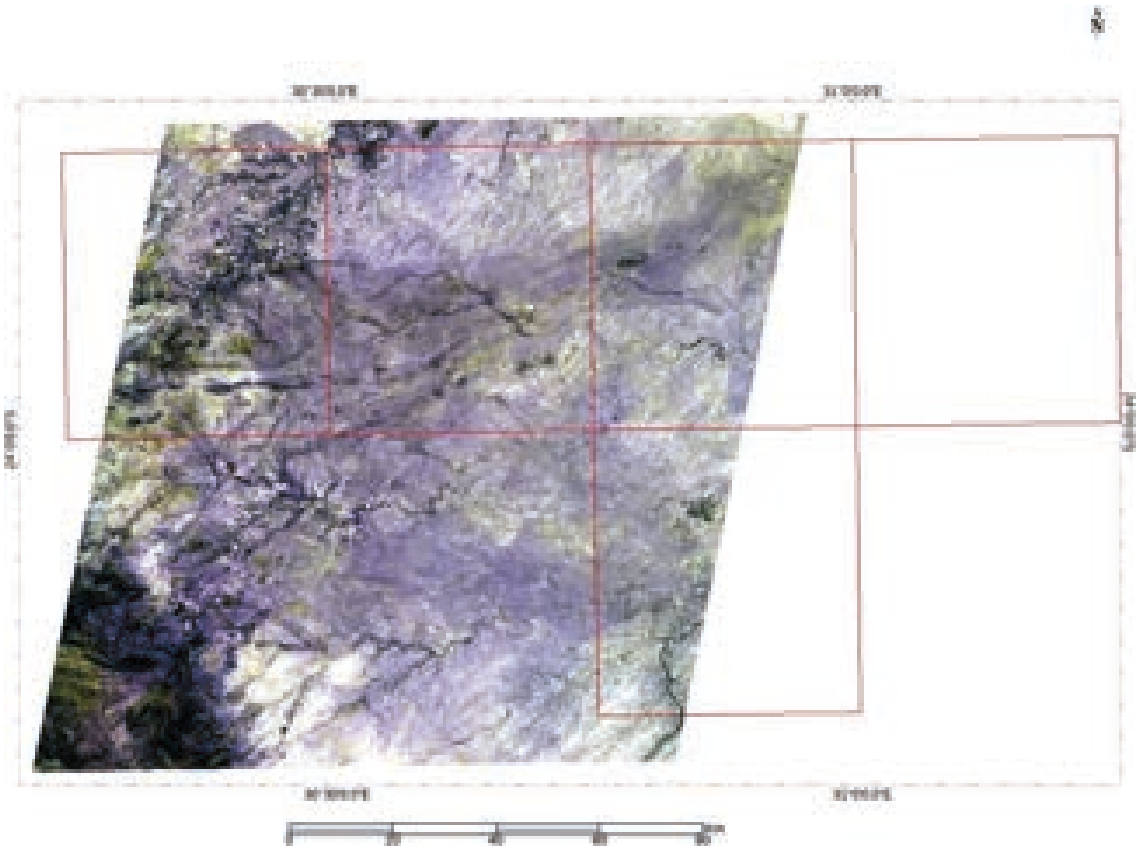

Fig. 5. Mosaicked ASTER SWIR stack of 21 Sep 2005 subsetted in ArcMap using the Clip tool (scenes IDs: $25492 \& 25491$ acquired on 21 Sep 2005) overlaid with five mapping sheets of Murchison Greenstone Belt area 
The option of colour correction (for radiometric normalisation through histogram matching to improve colour and tone consistency among the input scenes of the mosaic) was not selected in this step as pixel reflectance values will change while mosaicking and useful information for interpreting geology from band ratios will be lost. The FCC made from mosaicked stack of SWIR bands and VNIR bands that covered the extent of 8 mapping sheets are shown in Figures 6 and 7 (on the interleaf).

The Landsat 8 scenes processed for atmospheric correction were mosaicked in ENVI using Seamless Mosaic tool (Fig. 8 on the interleaf). Later this data was subsetted using study area polygon of 8 mapping sheets (Fig. 9 on the interleaf).

Using SNAP software, image displays for land/water discrimination was made using bands B5, B6 and B4 as RGB for a False Colour Composite (FCC) combination. The resulting product covering area of five mapping sheets is shown in Figure 10 (on the interleaf). Another FCC of healthy vegetation were prepared using band combination of B5, B6 and B2 in RGB form (Fig. 11 on the interleaf). These layers were later exported as GeoTiff format or Imagine file format raster files for displaying in ArcMap. Figure 11 reveals that the healthy vegetation shown in red are the agricultural patches seen in the north-western and western parts and the trees seen in the hilly region of the south-west part and along the river channels. There is not much healthy vegetation seen in the mapping sheets of Gravelotte, Mulati, Phalaborwa and Mica. The mining area of Phalaborwa region appears in blue.

\section{Data Processing for Discriminating Geological Features}

Advanced data processing techniques for image transformation using mathematical operations are often required to reveal hidden geological information such as outcrop extent, rock types, structural features and minerals formed due to alterations. Image transformation techniques refers to the operations applied on image bands to create new images to reveal or highlight certain features or objects of interest. Arithmetic operations such as addition, subtraction, multiplication and division are commonly applied to image bands or spectral bands through band math operators. An example of such image transformation is the calculation of the vegetation index using Normalised Difference Vegetation Index (NDVI). Available literature describing the utilization of different band combinations and band ratios of commonly used satellite images (Landsat, ASTER and Sentinel-2) for discriminating rocks types, geological features and alteration minerals were consulted first [19, 20]. As ASTER data are widely used in geological mapping, a comparison of spectral range (wavelengths) of Landsat 8 bands with ASTER bands was made to identify the equivalent ASTER bands available in Landsat 8 data (Tab. 1).

Using the information available in literature on commonly used band ratios and bands combinations for geological and mineral exploration studies, possible band ratios and other suitable band combinations for the ASTER and Landsat 8 data were experimentally tried in this study. 

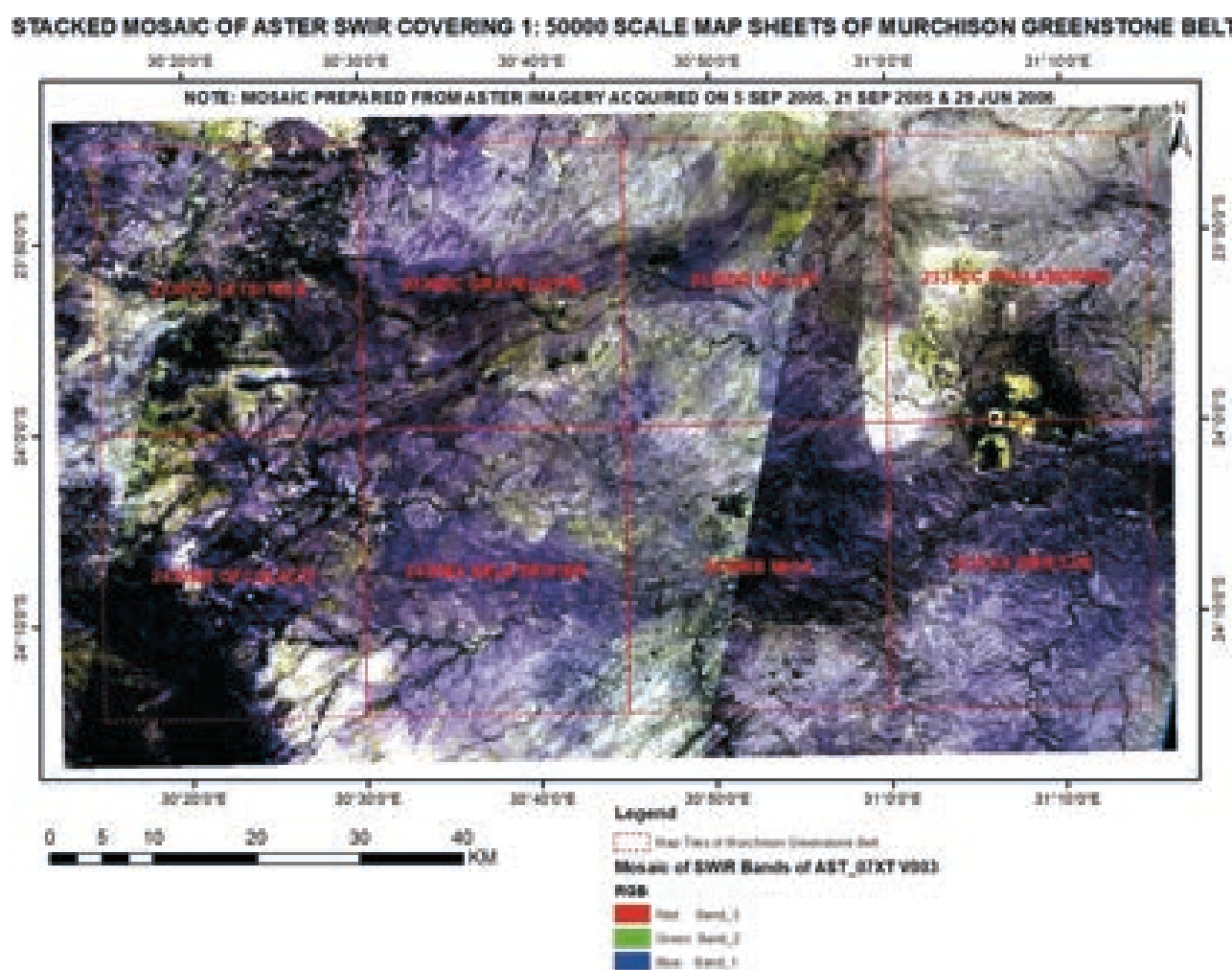

Fig. 6. FCC of Mosaicked and stacked ASTER SWIR data (acquired on 5 Sep 2005, 21 Sep 2005 and 29 Jun 2006)
covering eight mapping sheets of Murchison Greenstone Belt area
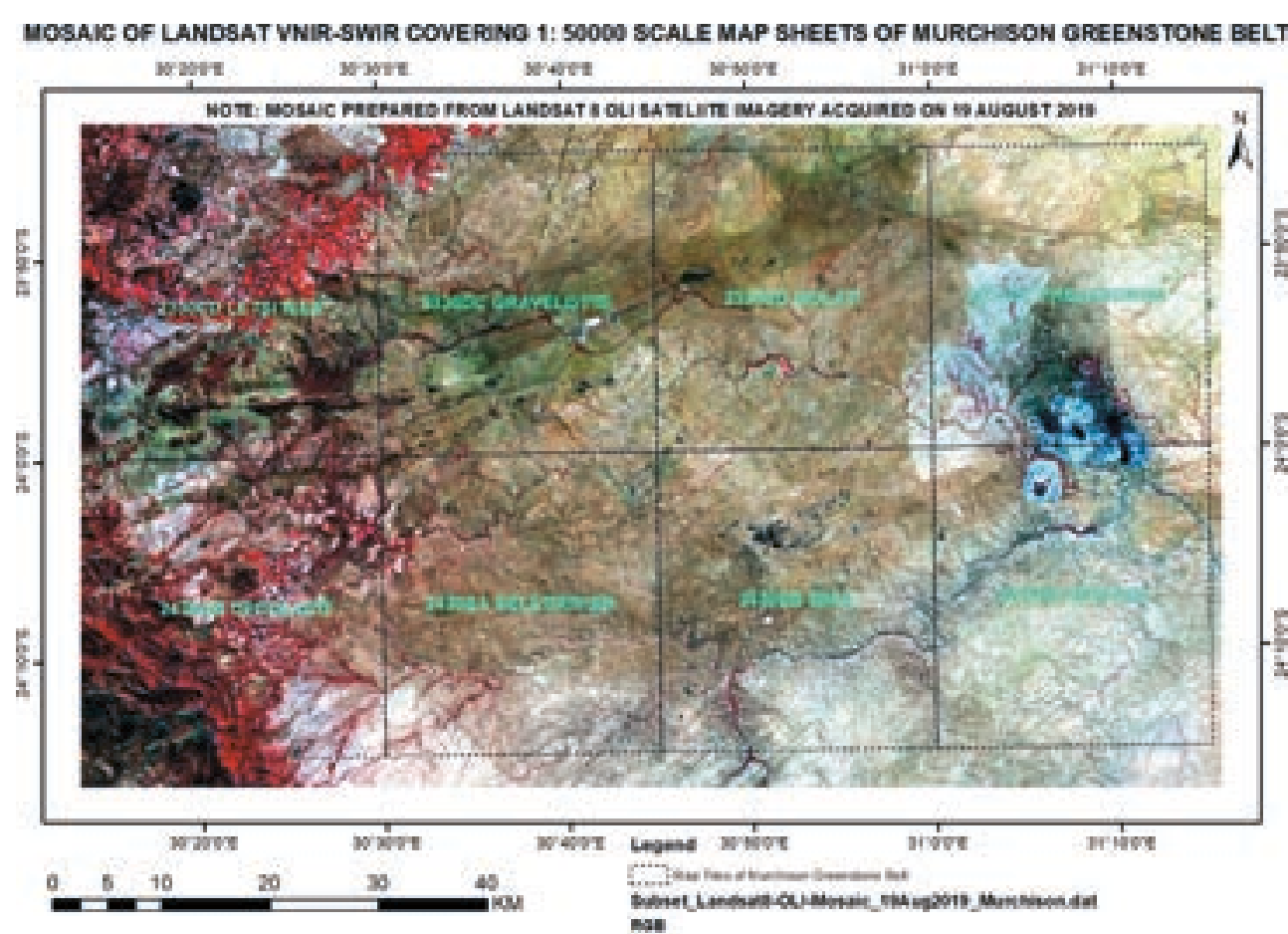

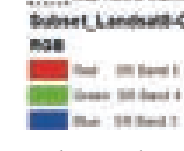

Fig. 9. Atmospherically corrected Landsat 8 level 2 product (RGB: B5-B4-B3)

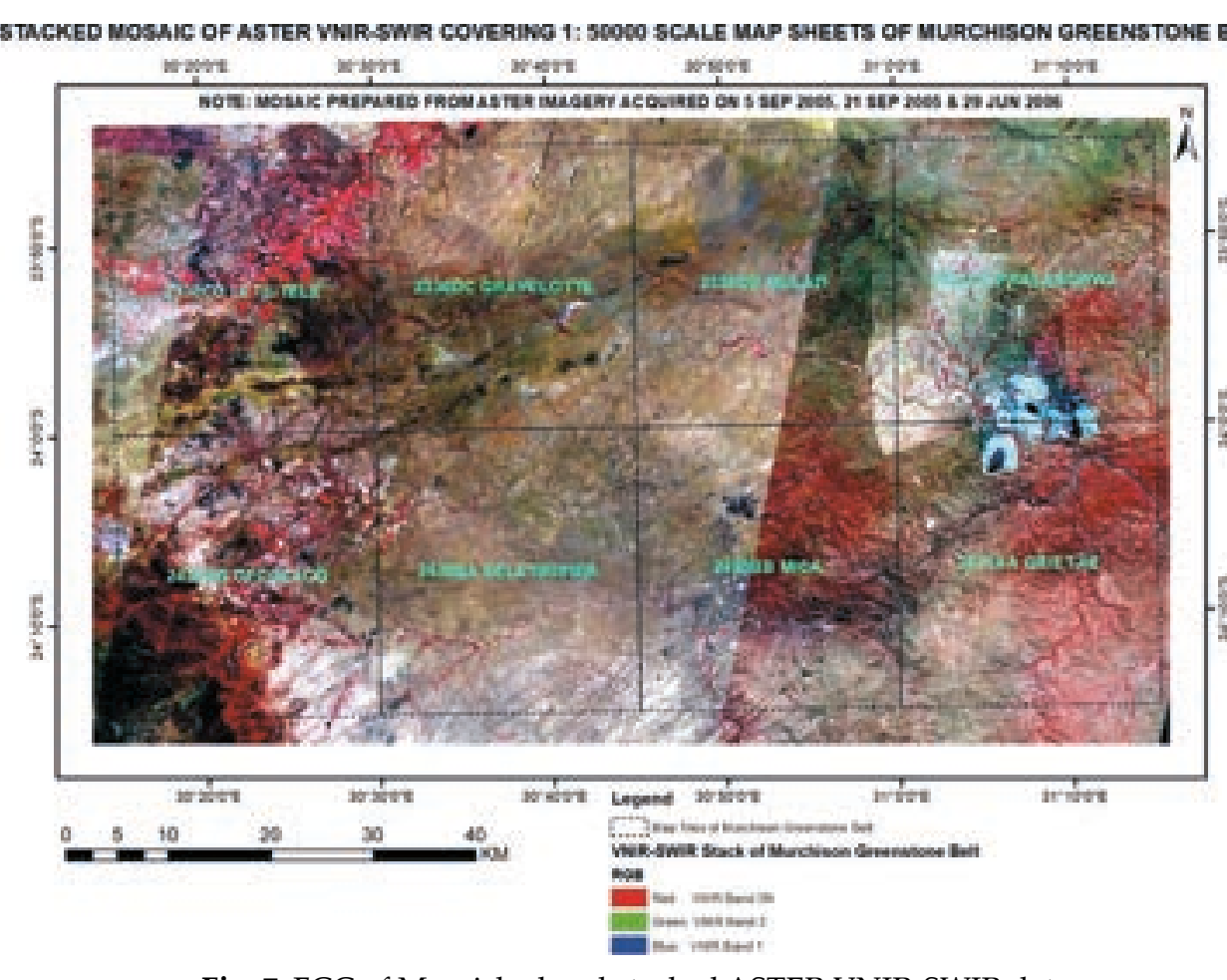

Fig. 7. FCC of Mosaicked and stacked ASTER VNIR-SWIR data covering eight mapping sheets of Murchison Greenstone Belt area

LAND I WATER DISPLAY OF FVE 1: S0000 SCALE MAPPING SHEETS OF MURCHISON QREENSTONE BELT

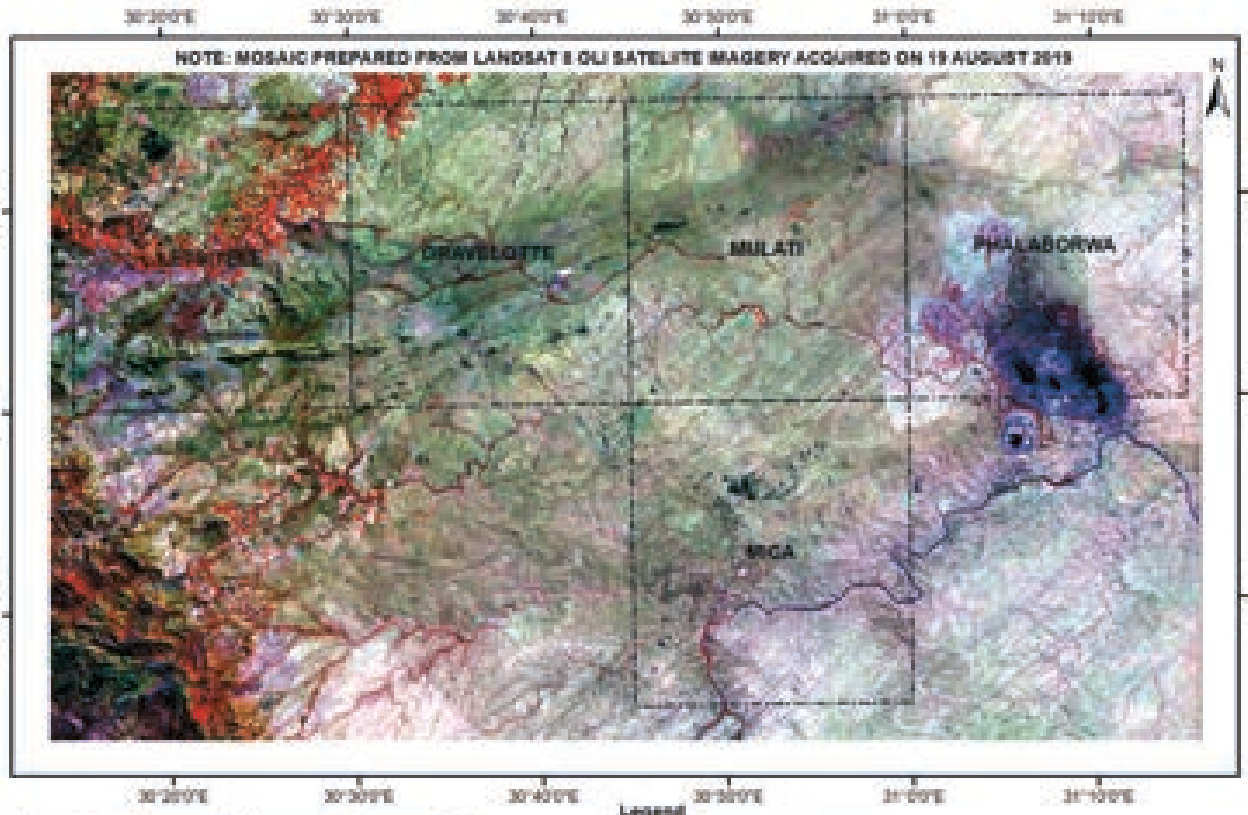

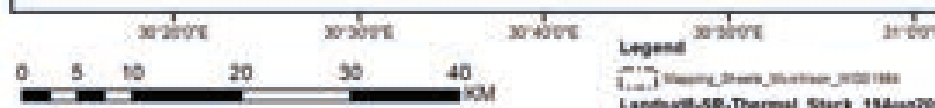
Nons

Fig. 10. Land/water display of Landsat 8 OLI datase

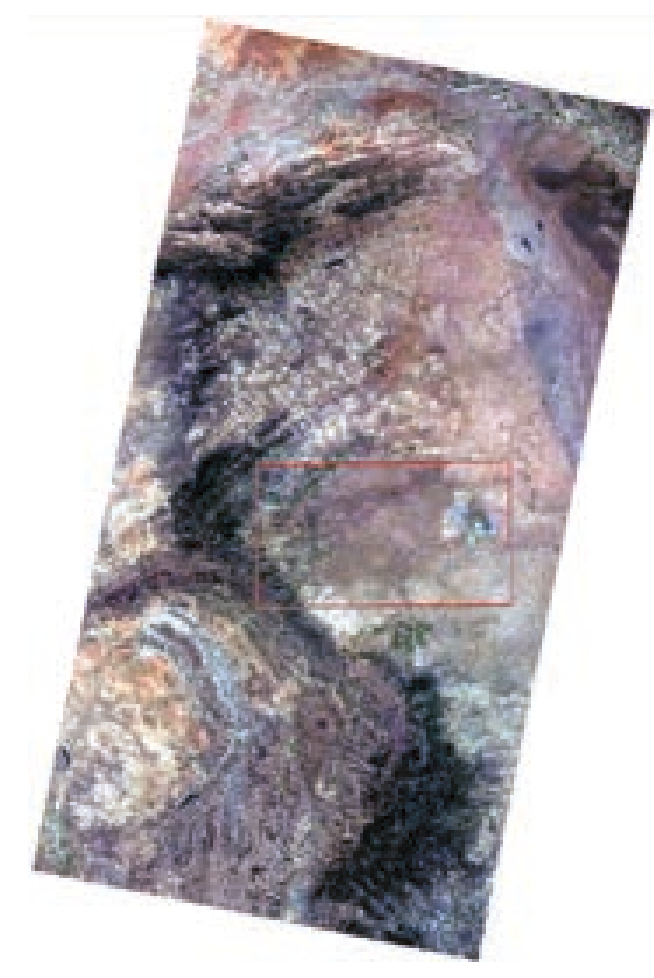

Fig. 8. Mosaic of atmospherically corrected true colour Landsat 8 OLI level 2 product overlaid with a polygon covering 8 mapping sheets

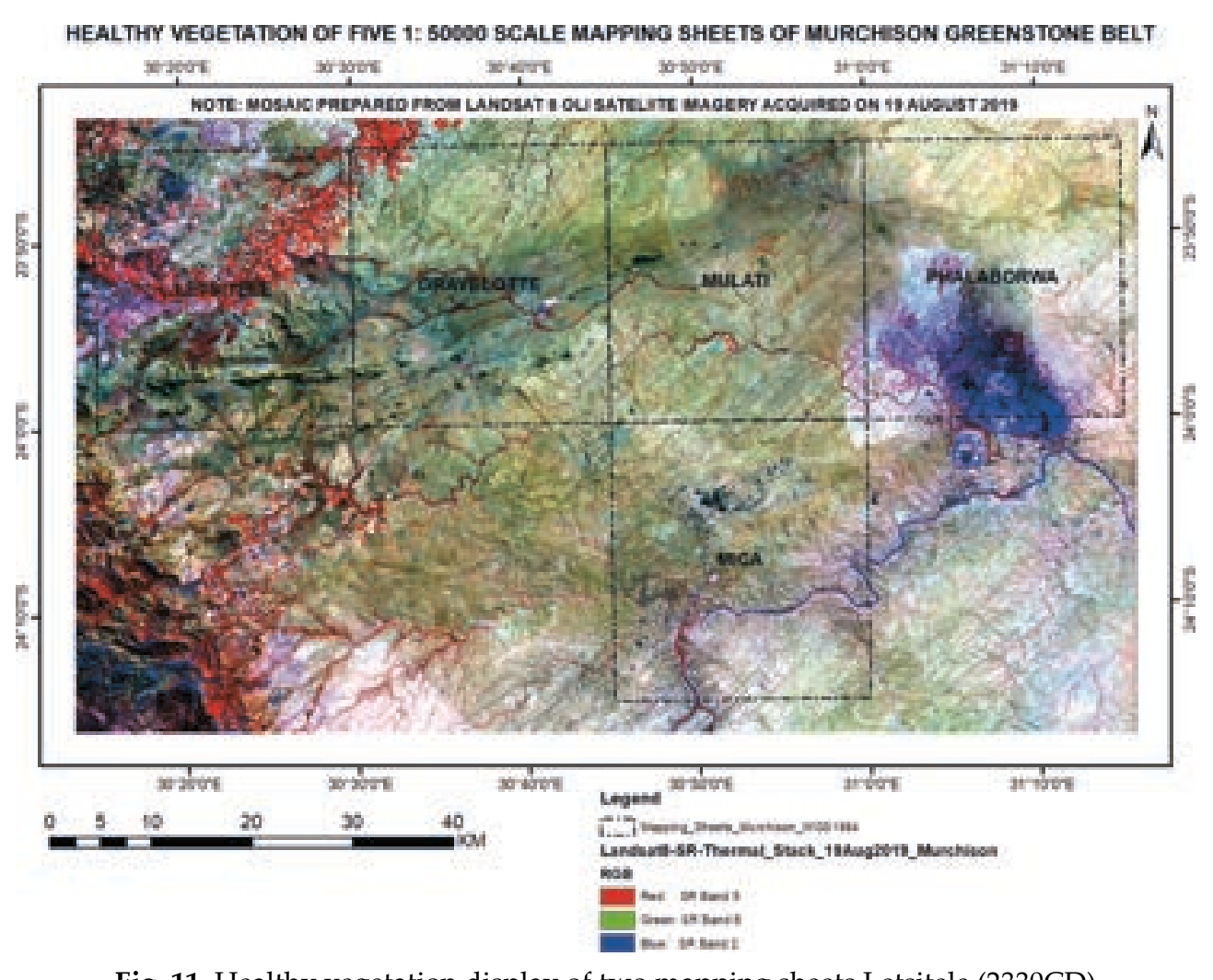

Fig. 11. Healthy vegetation display of two mapping sheets Letsitele (2330CD)
and Gravelotte (2330DC) using Sentinel-2B (RGB: B8, B11, B4) in Linear stretching in ENVI 
An attempt was also made to make PAN sharpened products and Minimum Noise Fraction (MNF) bands from Landsat 8 VNIR and SWIR bands. Good band ratio and band combinations that could discriminate geology and structural features were identified and compiled into two tables (Tabs. 2, 3).

Table 1. Comparison of spectral range of ASTER and Landsat 8 bands

\begin{tabular}{|c|c|}
\hline ASTER bands and spectral range $[\mu \mathrm{m}]$ & Equivalent Landsat $8 \mathrm{OLI} / \mathrm{TIRS}$ bands and spectral range $[\mu \mathrm{m}]$ \\
\hline Band $1(0.52-0.60)$ & Band $3(0.533-0.590)$ \\
\hline Band $2(0.63-0.69)$ & Band $4(0.636-0.676)$ \\
\hline Band $3(0.78-0.86)$ & Band $5(0.851-0.879)$ \\
\hline Band 4 (1.60-1.70) & Band $6(1.566-1.651)$ \\
\hline Band 5 (2.145-2.185) & \multirow{2}{*}{ Band 7 (2.107-2.294) } \\
\hline Band $6(2.185-2.225)$ & \\
\hline Band 13 (10.25-10.95) & Band $10(10.6-11.19)$ \\
\hline Band $14(10.95-11.65)$ & Band $11(11.5-12.51)$ \\
\hline
\end{tabular}

Source: $[21,22]$

Table 2. ASTER bands \& band ratios used in RGB display for identifying geological and land features

\begin{tabular}{|l|c|c|c|c|c||}
\hline \multicolumn{1}{|c|}{ Features } & Red & Green & Blue & Reference & Colour display \\
\hline \hline Descrimination of geology & B4/B7 & B4/B3 & B2/B1 & $\begin{array}{c}\text { Abrams } \\
\text { (USGS) }\end{array}$ & - \\
\hline Descrimination of geology & B4/B7 & B4/B1 & $\begin{array}{c}\text { B2/ } \\
\text { B3xB4/ } \\
\text { B3 }\end{array}$ & Sultan & - \\
\hline $\begin{array}{l}\text { Descrimination of geology/ } \\
\text { lithology }\end{array}$ & B6 & B3 & B1 & - & $\begin{array}{c}\text { pink (granites), } \\
\text { red/purple (gabbro) }\end{array}$ \\
\hline $\begin{array}{l}\text { Descrimination of geology/ } \\
\text { lithology }\end{array}$ & B4 & B3 & B1 & - & $\begin{array}{c}\text { pink (granites), } \\
\text { red/purple (gabbro) }\end{array}$ \\
\hline $\begin{array}{l}\text { Enhanced structural features/ } \\
\text { lineaments }\end{array}$ & B7 & B4 & B2 & $\begin{array}{c}\text { Rowan } \\
\text { (USGS) }\end{array}$ & $\begin{array}{c}\text { pink (granites), } \\
\text { red/purple (gabbro) }\end{array}$ \\
\hline $\begin{array}{l}\text { Descrimination of gossan, } \\
\text { alteration \& host rock }\end{array}$ & B6 & B2 & B1 & - & - \\
\hline $\begin{array}{l}\text { Descrimination of gossan, } \\
\text { alteration \& host rock }\end{array}$ & B4/B2 & B4/B5 & B5/B6 & Volesky & - \\
\hline $\begin{array}{l}\text { Geology discrimination/ } \\
\text { alteration }\end{array}$ & B4/B1 & B4/B5 & B4/B7 & - & - \\
\hline
\end{tabular}


Table 2 cont.

\begin{tabular}{|c|c|c|c|c|c|}
\hline Features & Red & Green & Blue & Reference & Colour display \\
\hline Clay, amphibole, laterite & $\begin{array}{c}(\mathrm{B} 5 \times \mathrm{B} 7) / \\
\mathrm{B} 6 \times \mathrm{B} 6\end{array}$ & B6/B8 & B4/B5 & Bierwith & - \\
\hline Vegetation & B3 & B2 & B1 & - & vegetation in red \\
\hline Descrimination of vegetation & B3/B2 & B2 & B1 & - & vegetation in red \\
\hline Healthy vegetation & B3 & B4 & B1 & $\begin{array}{l}\text { SNAP } \\
\text { software }\end{array}$ & vegetation in red \\
\hline Land/water & B3 & B4 & B2 & $\begin{array}{l}\text { SNAP } \\
\text { software }\end{array}$ & water (black) \\
\hline $\begin{array}{l}\text { Descrimination of built-up } \\
\text { and roads }\end{array}$ & B4 & B6 & B4/B6 & - & yellow \\
\hline $\begin{array}{l}\text { AlOH minerals/ } \\
\text { argillic alteration }\end{array}$ & B5/B6 & B7/B6 & B7/B5 & $\begin{array}{l}\text { Hewson } \\
\text { (CSIRO) }\end{array}$ & - \\
\hline $\begin{array}{l}\text { Carbonate-chlorite-epidote- } \\
\text {-amphibole }\end{array}$ & $\begin{array}{l}\mathrm{B} 7+\mathrm{B} 9 / \\
\mathrm{B} 8\end{array}$ & $\begin{array}{l}\mathrm{B} 6+\mathrm{B} 9 / \\
\mathrm{B} 7+\mathrm{B} 8\end{array}$ & B6/B8 & $\begin{array}{l}\text { Kalinowski } \\
\text { \& Oliver }\end{array}$ & $\begin{array}{l}\text { carbonate rock } \\
\text { in purple }\end{array}$ \\
\hline
\end{tabular}

Table 3. Landsat 8 bands and band ratios used in RGB display for identifying geological and land features

\begin{tabular}{|c|c|c|c|c|c|}
\hline Features & Red & Green & Blue & Reference & Colour display \\
\hline Descrimination of geology & B7 & B6 & B5 & - & - \\
\hline Descrimination of geology & B5 & B6 & B7 & $\begin{array}{l}\text { Banerjee } \\
\text { et al. }\end{array}$ & - \\
\hline $\begin{array}{l}\text { Descrimination of geology/ } \\
\text { lithology }\end{array}$ & B10 & B7 & B6 & - & $\begin{array}{l}\text { gneisses/granites (blue), } \\
\text { mafics (purple/orange) }\end{array}$ \\
\hline $\begin{array}{l}\text { Descrimination of geology/ } \\
\text { lithology }\end{array}$ & B11 & B7 & B6 & - & gneisses and granites in blue \\
\hline $\begin{array}{l}\text { Descrimination of geology/ } \\
\text { lithology }\end{array}$ & B10 & B6 & B7 & - & $\begin{array}{c}\text { gneisses/granites (green), } \\
\text { mafics (pink) }\end{array}$ \\
\hline $\begin{array}{l}\text { Descrimination of alteration/ } \\
\text { lithology }\end{array}$ & $\mathrm{B} 4 / \mathrm{B} 2$ & B6/B7 & B10 & $\begin{array}{c}\text { Pour } \\
\text { \& Hashim }\end{array}$ & - \\
\hline $\begin{array}{l}\text { Descrimination of alteration/ } \\
\text { lithology }\end{array}$ & $\mathrm{B} 4 / \mathrm{B} 2$ & B6/B7 & B5 & $\begin{array}{c}\text { Pour } \\
\text { \& Hashim }\end{array}$ & - \\
\hline $\begin{array}{l}\text { Descrimination of geology/ } \\
\text { lithology }\end{array}$ & B7 & B5 & B2 & - & $\begin{array}{l}\text { mafic/ultramafic in pink, } \\
\text { gneiss in blue }\end{array}$ \\
\hline $\begin{array}{l}\text { Descrimination of geology/ } \\
\text { lithology }\end{array}$ & B7 & B5 & B3 & $\begin{array}{c}\text { Amusuk } \\
\text { et al. }\end{array}$ & $\begin{array}{l}\text { mafic/ultramafic in pinkish } \\
\text { brown, gneiss in blue }\end{array}$ \\
\hline $\begin{array}{l}\text { Descrimination of structure/ } \\
\text { lithology/vegetation }\end{array}$ & B5 & B4 & B3 & - & $\begin{array}{l}\text { mafic/ultramafic in greenish } \\
\text { brown, veg (red) }\end{array}$ \\
\hline
\end{tabular}


Table 3 cont.

\begin{tabular}{|c|c|c|c|c|c|}
\hline Iron oxides and clay minerals & B2 & B5 & B7 & - & purple and pink shades \\
\hline Ferrous and clay minerals & B6/B5 & B6/B7 & B4/B2 & - & red and green \\
\hline Ferrous and clay minerals & B4/B2 & B6/B5 & B6/B7 & - & green and blue \\
\hline Alteration minerals & B4/B2 & B6/B7 & B5/B4 & - & blue \\
\hline Lithology and structures & B5 & B3 & B2 & - & $\begin{array}{l}\text { mafic/ultramafic in purple, } \\
\text { gneiss in white }\end{array}$ \\
\hline $\begin{array}{l}\text { Lithology and structures } \\
\text { from MNF bands }\end{array}$ & MNF1 & MNF2 & MNF3 & $\begin{array}{l}\text { Ourhzif } \\
\text { et al. }\end{array}$ & - \\
\hline $\begin{array}{l}\text { Lithology and structures } \\
\text { from MNF bands }\end{array}$ & MNF5 & MNF2 & MNF1 & - & - \\
\hline $\begin{array}{l}\text { Lithology and structures } \\
\text { from MNF bands }\end{array}$ & MNF5 & MNF2 & MNF3 & $\begin{array}{l}\text { Prasath } \\
\text { \& Kusuma }\end{array}$ & - \\
\hline $\begin{array}{l}\text { Lithology and structures } \\
\text { from pan-sharpened }\end{array}$ & PS-B5 & PS-B4 & PS-B3 & - & mafic/ultramafic in brown \\
\hline $\begin{array}{l}\text { Lithology and structures } \\
\text { from pan-sharpened }\end{array}$ & PS-B6 & PS-B4 & PS-B2 & - & $\begin{array}{l}\text { mafic/ultramafic in reddish } \\
\text { brown }\end{array}$ \\
\hline $\begin{array}{l}\text { Discrimination of lithology } \\
\text { and structures }\end{array}$ & B7/B6 & B5 & slope & - & outcrop in blue and purple \\
\hline $\begin{array}{l}\text { Discrimination of lithology } \\
\text { and structures }\end{array}$ & B7/B6 & B7 & slope & - & outcrop in blue and purple \\
\hline $\begin{array}{l}\text { Discrimination of lithology } \\
\text { and structures }\end{array}$ & B7 & B6 & slope & - & outcrop in blue \\
\hline $\begin{array}{l}\text { Discrimination of lithology } \\
\text { and structures }\end{array}$ & B5 & B7 & slope & - & outcrop in blue \\
\hline Land/water & B5 & B6 & B4 & $\begin{array}{l}\text { SNAP } \\
\text { software }\end{array}$ & $\begin{array}{c}\text { water in black, vegetation in red } \\
\text { and brown }\end{array}$ \\
\hline Healthy vegetation & B5 & B6 & B2 & $\begin{array}{l}\text { SNAP } \\
\text { software }\end{array}$ & vegetation in red and brown \\
\hline
\end{tabular}

Using the compilation given in Tables 2 and 3, possible band ratios were calculated first. Identified bands, band ratio images and FCC combinations shown in these tables were displayed in ENVI as FCCs in RGB format. Image enhancement tools available in ENVI software such as Linear 2\% Enhancement, was applied on the displayed products for discriminating geology/lithology, structural features and lineaments, alteration and iron oxides, land/water, surface features, vegetation cover and healthy vegetation etc. These layers were later exported as GeoTIFF format files for displaying in ArcMap by the mapping geologists. 
The one arc ASTER DEM data (version 3) covered in four tiles were initially mosaicked using the seamless mosaic tool of ENVI and projected to UTM 36 South projection. This data was subsetted for the extent of the area of interest using a rectangle polygon that covered eight mapping sheets. Later, the DEM was resized/resampled to $30 \mathrm{~m}$ pixel size in both $\mathrm{X}$ and $\mathrm{Y}$ directions using the ENVI software. The DEM layer was processed further in ArcMap to fill all the sinks using the Fill tool available with the Spatial Analyst Extension. This filled (depression free) DEM was later processed in ENVI Classic using the Topographic Modelling tool for producing a slope map in degrees (Fig. 12 on the interleaf) and saved as Geotiff file for making identified FCCs using a stacked set. The subsetted DEM was later processed in ENVI software to produce three hill shaded relief images at 45 degrees sun elevation for three different azimuth directions of 0, 120 and 240 degrees. A FCC made in RGB using 240 degree azimuth- 0 degree azimuth-120 degree azimuth as band combinations enabled identification of some structural features (especially ridges, outcrops), drainage network and lineaments (Fig. 13 on the interleaf).

\section{Results Displaying Discriminating Geological Features}

The data analysis produced 16 layers or FCCs from ASTER data and 26 layers from Landsat 8 data. Figures 14-19 (on the interleaf) show the selected FCCs generated from different image (band or band ratio) combinations of ASTER data that help to identify or discriminate geological features (structures, outcrops, lithology, lineaments, vegetation and alteration etc.) of the 5 mapping sheets of MGB area. In Figure 14, the red regions are mainly of tonalite and diorite, whereas the greenish yellow and light blue regions are of respectively medium grained and coarse grained granodioritic biotite-muscovite granite. The yellow and orange shades show mafic and ultramafic rocks (metagabbro and mafic metavolcanics).

In Figure 15, the granitic regions appear in pink shades; the purple regions are underlain by mafic and ultramafic rocks. The green regions seen in the eastern part are underlain by tonalite and granodiorite whereas the green patches seen towards the south-western corner are of basalt and dolomitic shale covered with thick vegetation. The green patches seen in the north-western part is agricultural land underlain by gabbro.

Structural features, dykes and outcropping rocks are prominent in Figure 16. The white and light-yellow regions are of granite whereas the green patches seen in the south-eastern part are of tonalite and granodiorite; the red patch seen in the south-western corner is mainly of dolomite. The smooth green patches seen in the northern part represents the mafic and ultramafic rocks. Figure 17 shows distinct host rocks of the study area in different colour shades along with alteration regions. Figures 18 and 19 show possible mineral identification regions for clay, amphibole, laterite, carbonate, chlorite, epidote etc. 

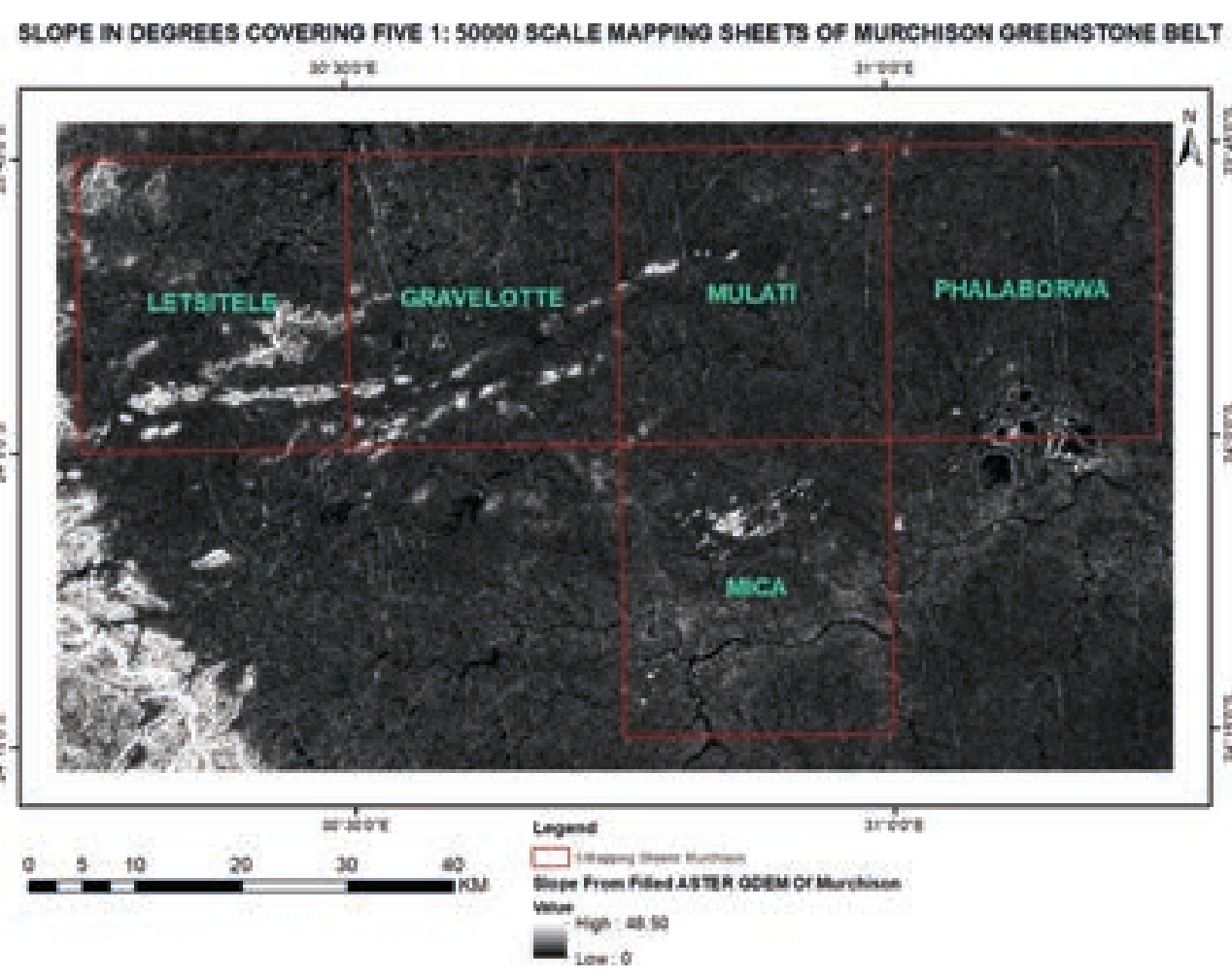

Fig. 12. Slope in degrees derived from ASTER Global Digital Elevation Model (GDEM) covering five mapping sheets of Murchison Greenstone Belt

\section{GEOLOGY DISCRMMINATION OF FIVE 1:50,000 SCALE MAPPING SHEETS OF MURCHISON GREENSTONE BELT}
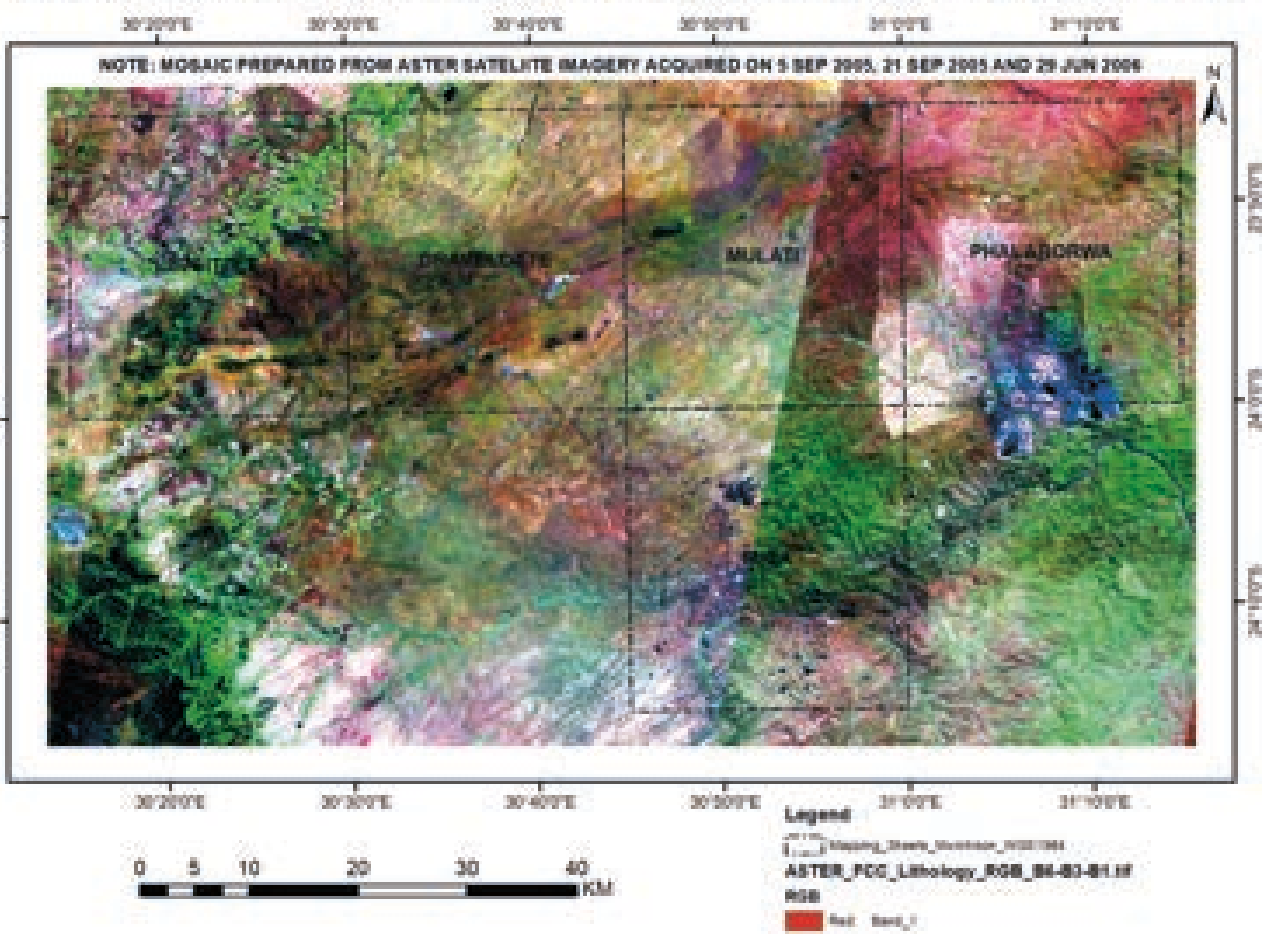

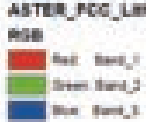
Fig. 15. Discrimination of lithology and geological features from ASTER data
using FCC of RGB: B6-B3-B1 covering Murchison Greenstone Belt
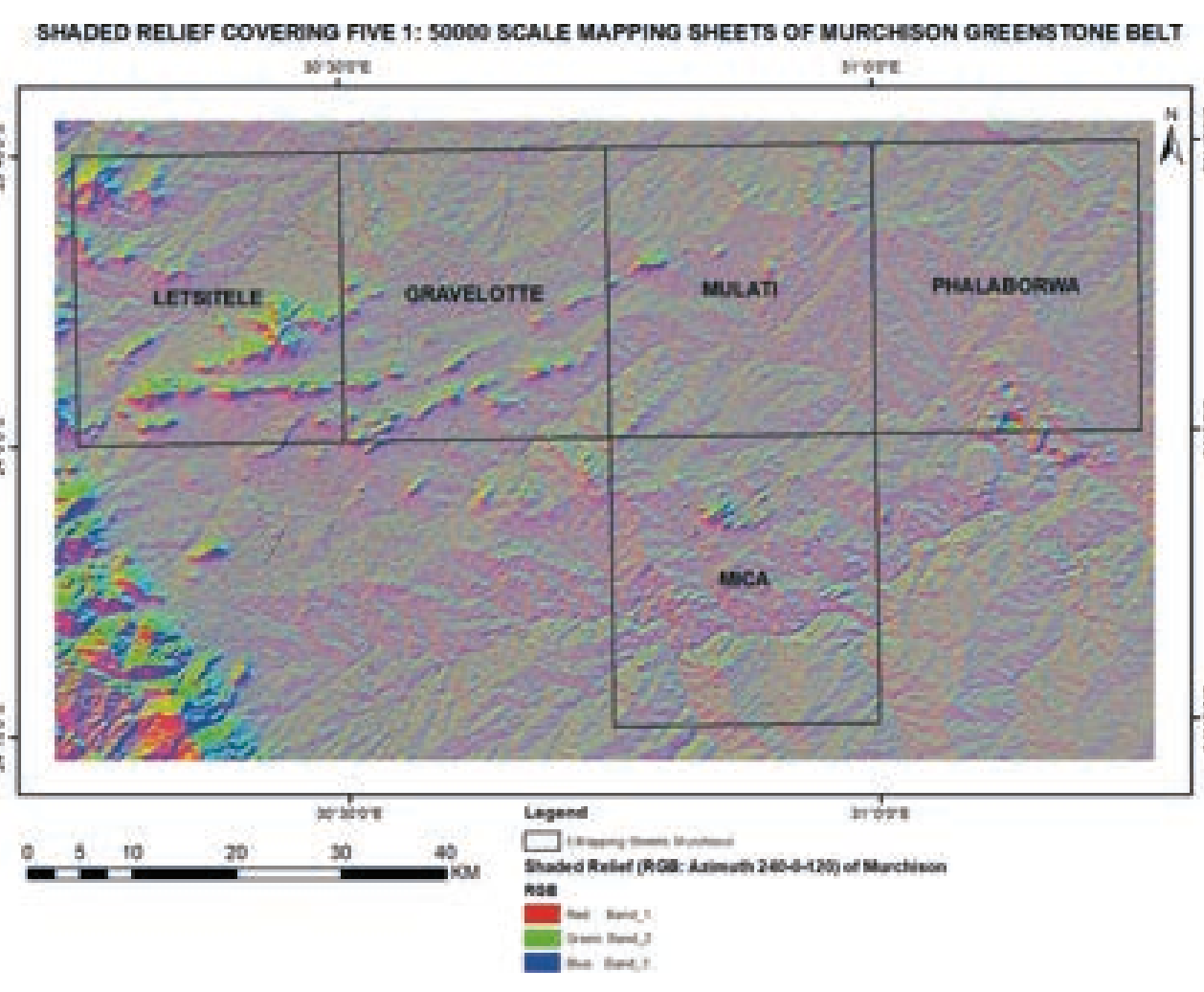

Fig. 13. Shaded relief in RGB: $240-0-120$ degrees derived from ASTER DEM for five mapping sheets Murchison Greenstone Belt

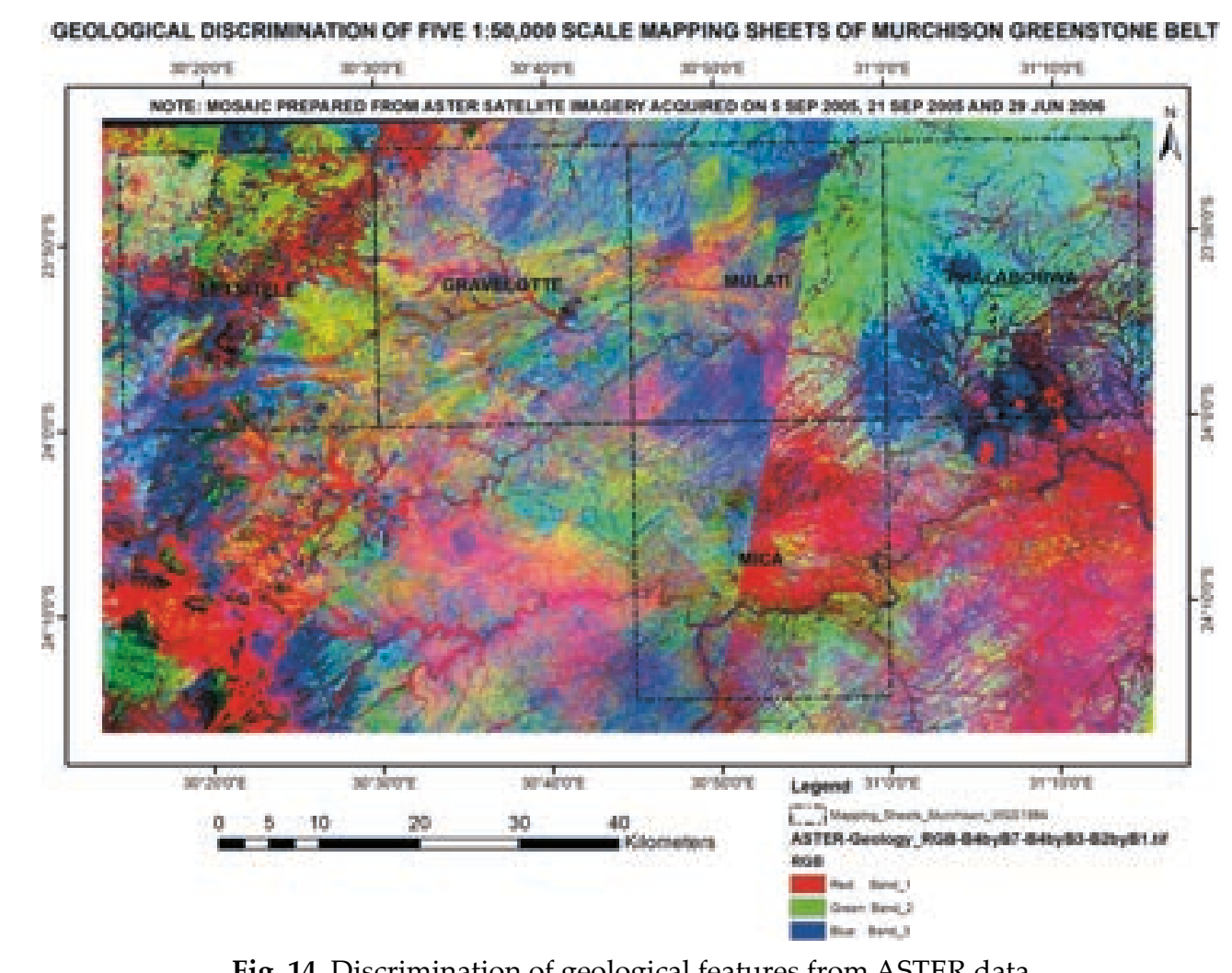

Fig. 14. Discrimination of geological features from ASTER data
using FCC of RGB: B4/B7-B4/B3-B2/B1 covering Murchison Greenstone B

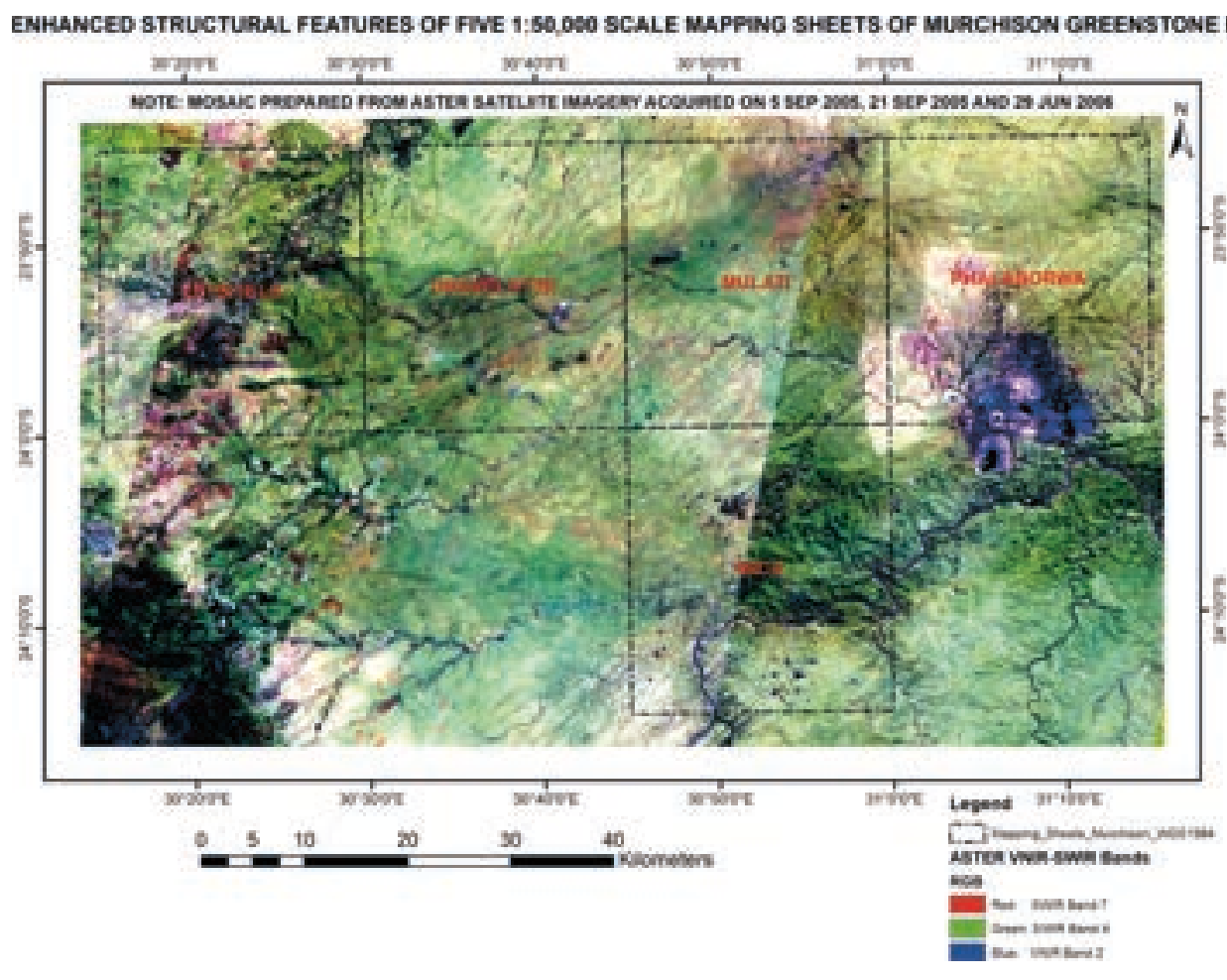
Fig. 16. Structural features and lineaments identifiable from ASTER data
using FCC of RGB: B7-B4-B2 covering Murchison Greenstone Belt

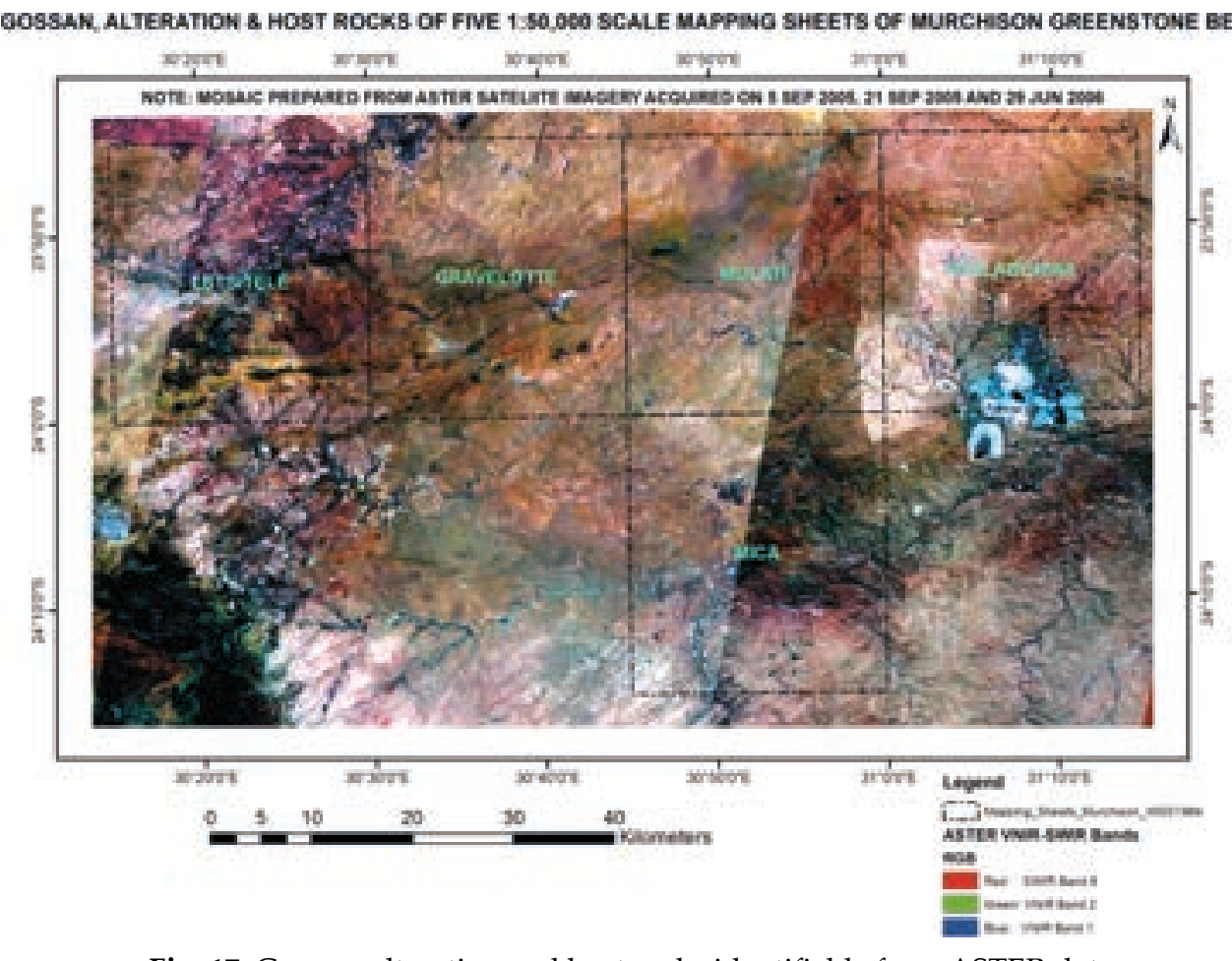

Fig. 17. Gossan, alteration and host rocks identifiable from ASTER data
using FCC of RGB: B6-B2-B1 covering Murchison Greenstone Belt 


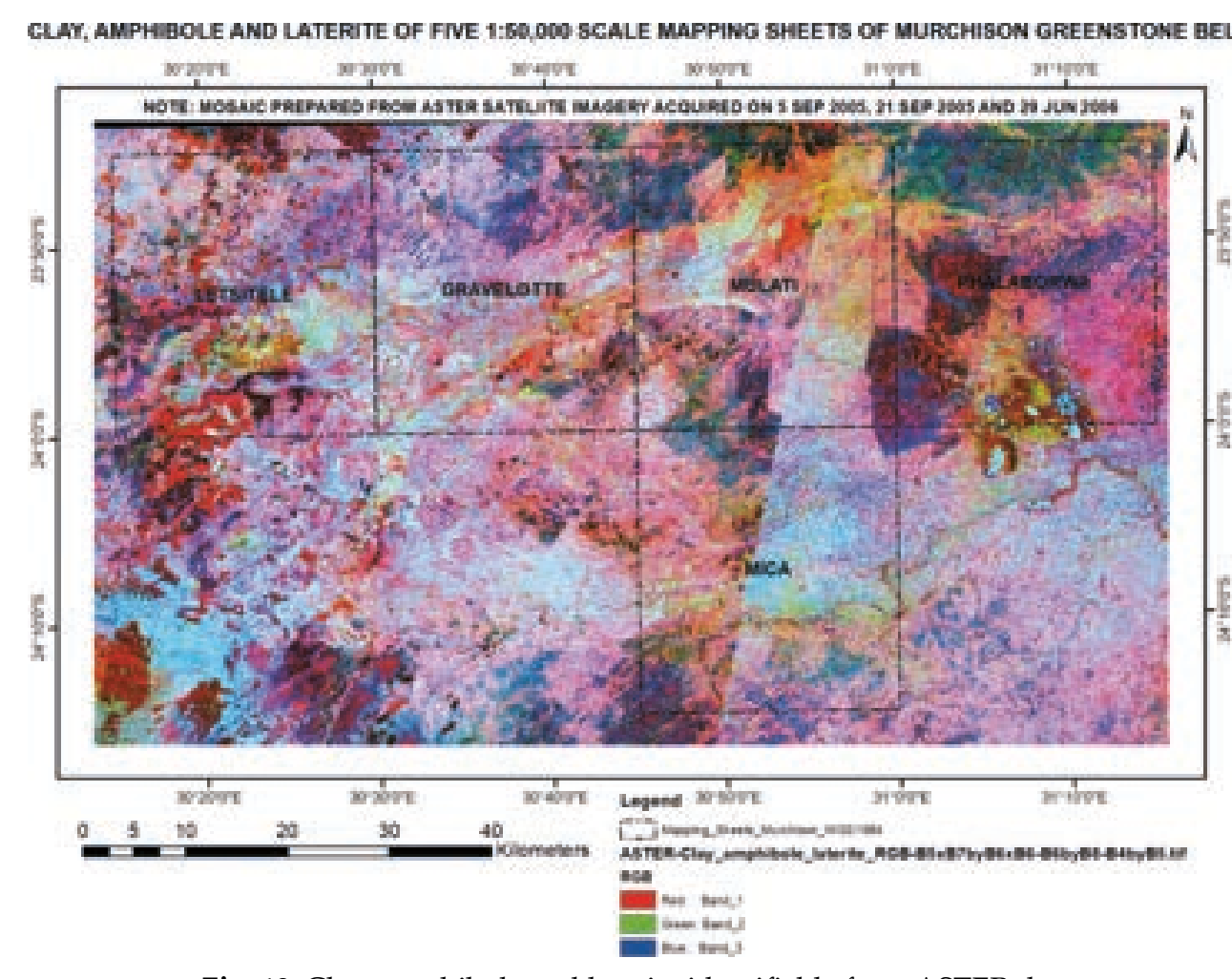

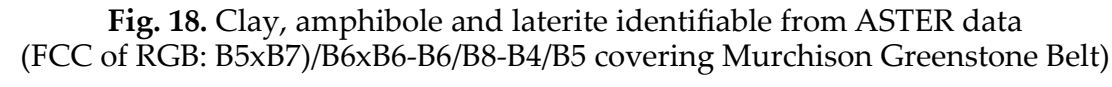
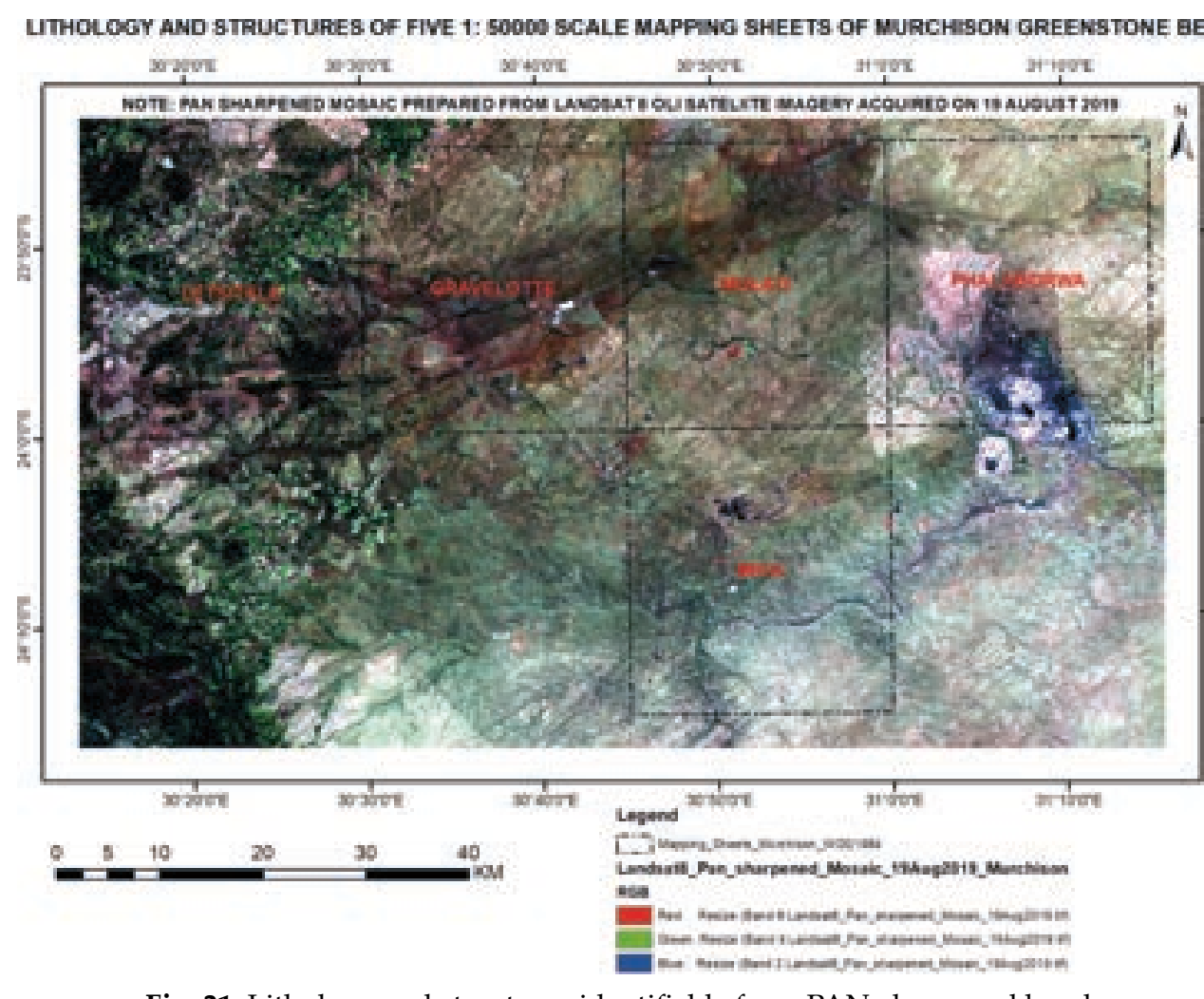

Fij. 21. Lithology and structures identifiable from PAN-sharpened bands
of Landsat 8 (RGB: PS_B6-PS_B4-PS_B2) covering Murchison Greenstone Belt

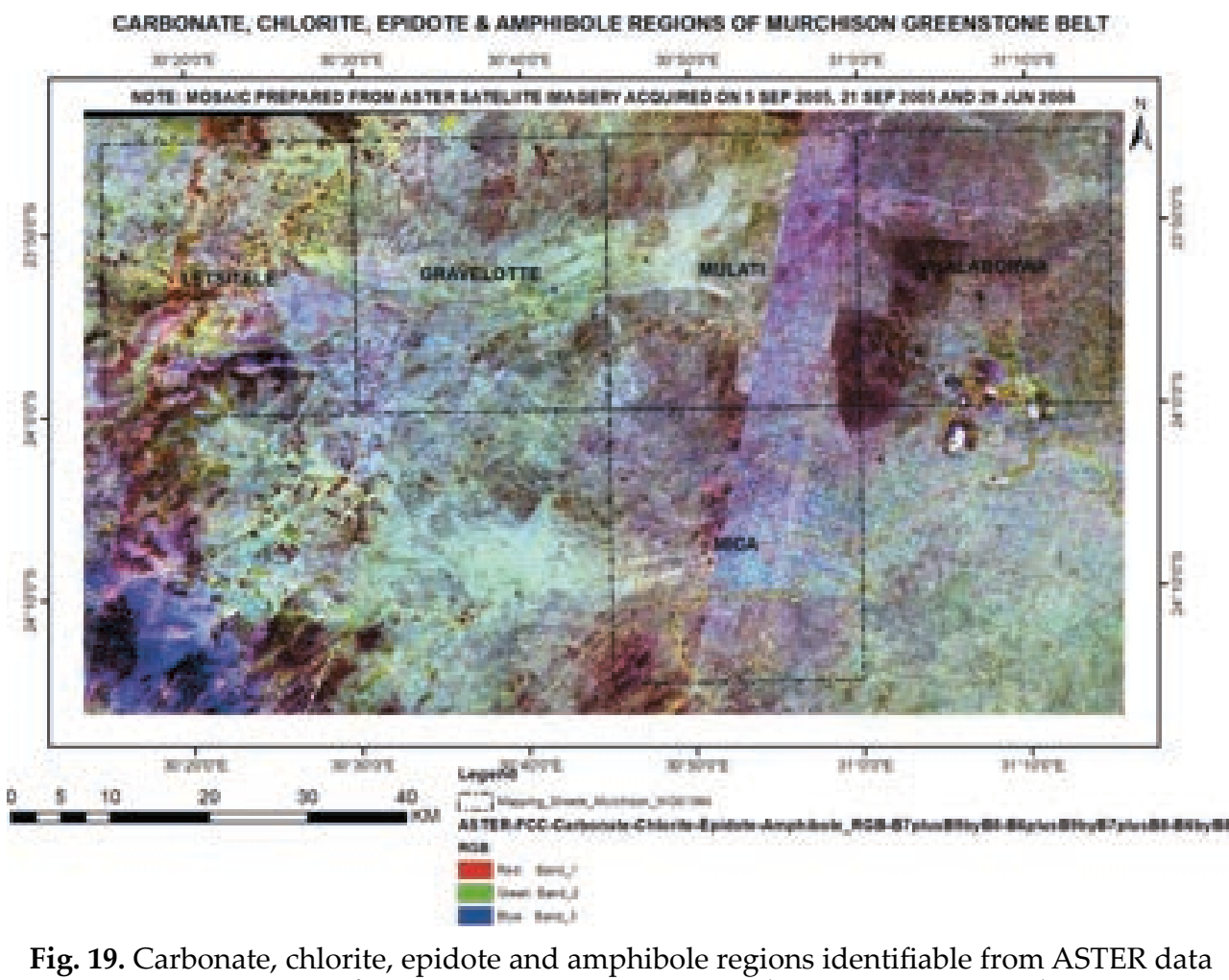
Fig. 19. Carbonate, chlorite, epidote and amphibole regions identifiable from ASTER data
using FCC of RGB: B3-B4-B2 covering Murchison Greenstone Belt
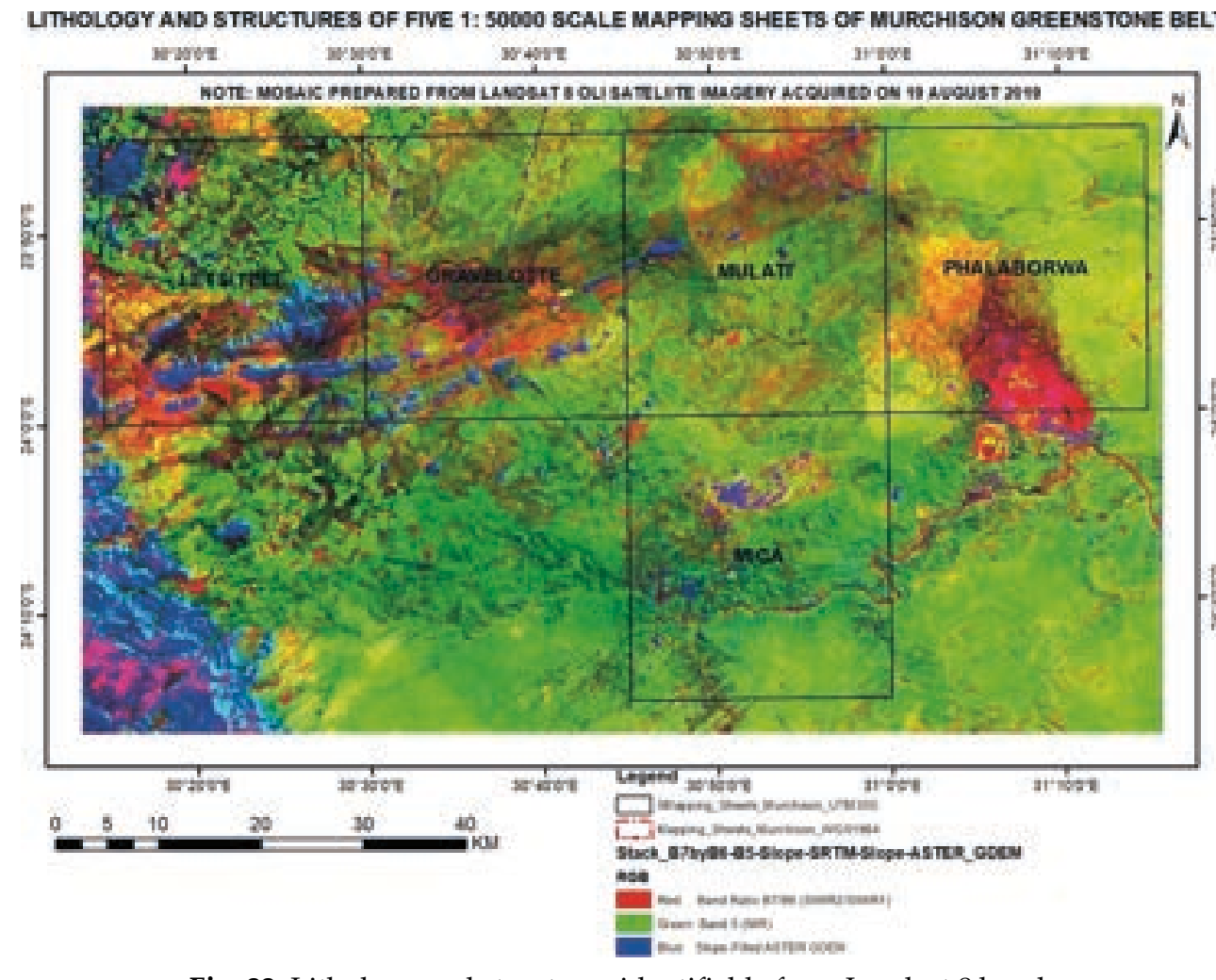

Fig. 22. Lithology and structures identifiable from Landsat 8 bands
and slope (RGB: B7/B6-B5-Slope) covering Murchison Greenstone Belt

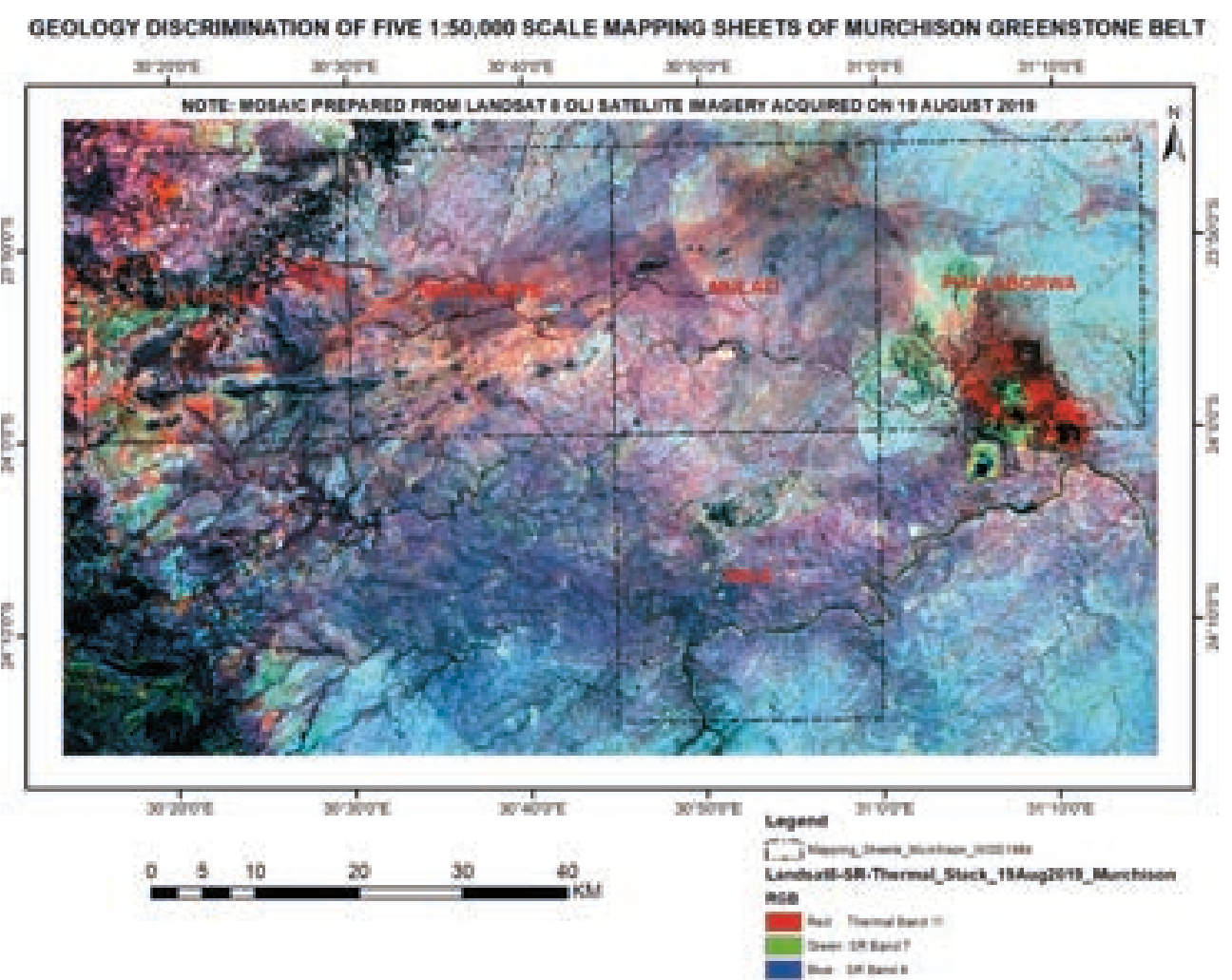

Fig. 20. Geology discrimination identifiable from Landsat 8 data
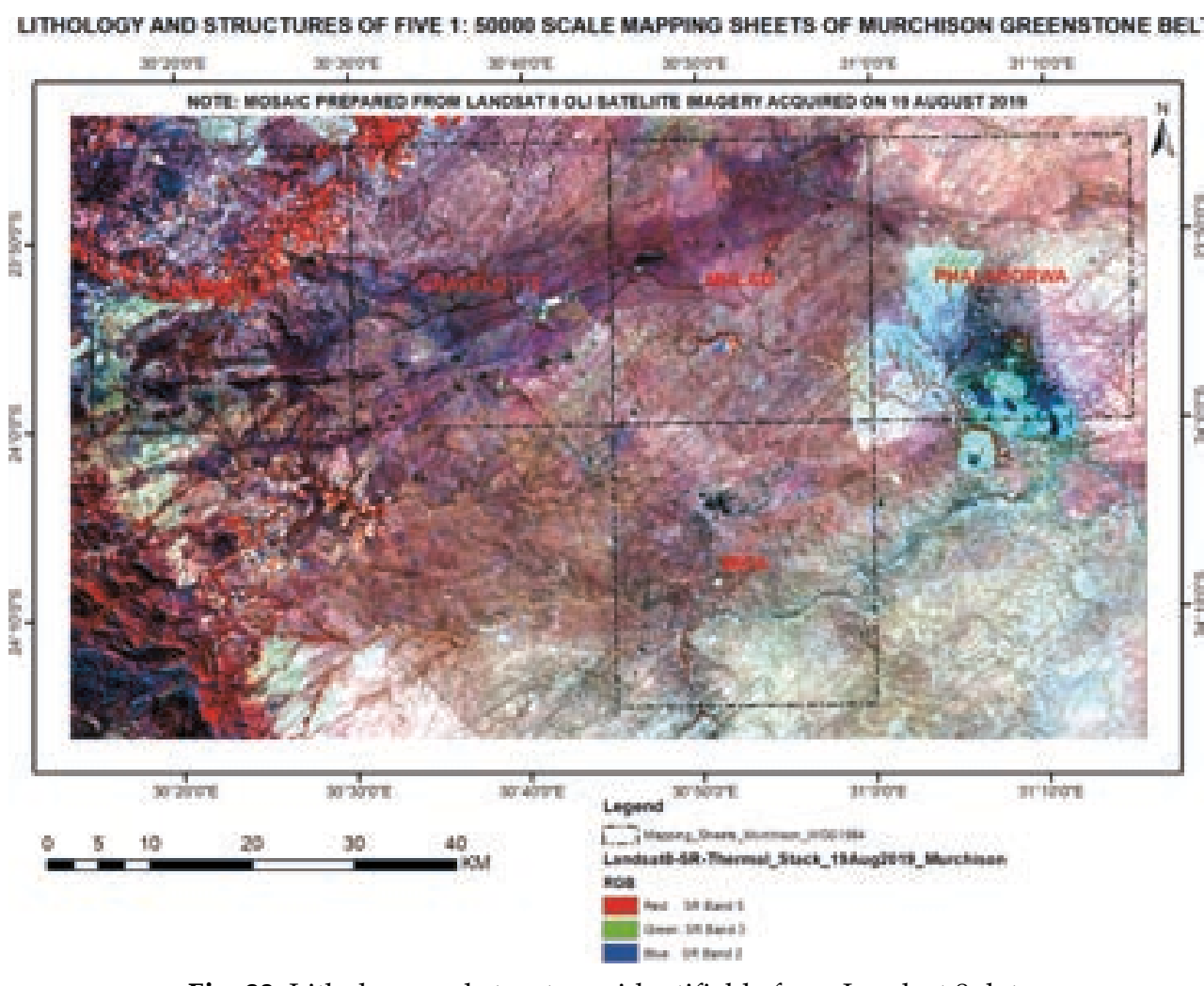

Fig. 23. Lithology and structures identifiable from Landsat 8 data
using FCC of RGB: B5-B3-B2 covering Murchison Greenstone Belt 
UTHOLOOY AND STRUCTURES OF FIVE 1: 50000 SCALE MAPPNO SHEETS OF MURCHESON GREENSTONE BELT

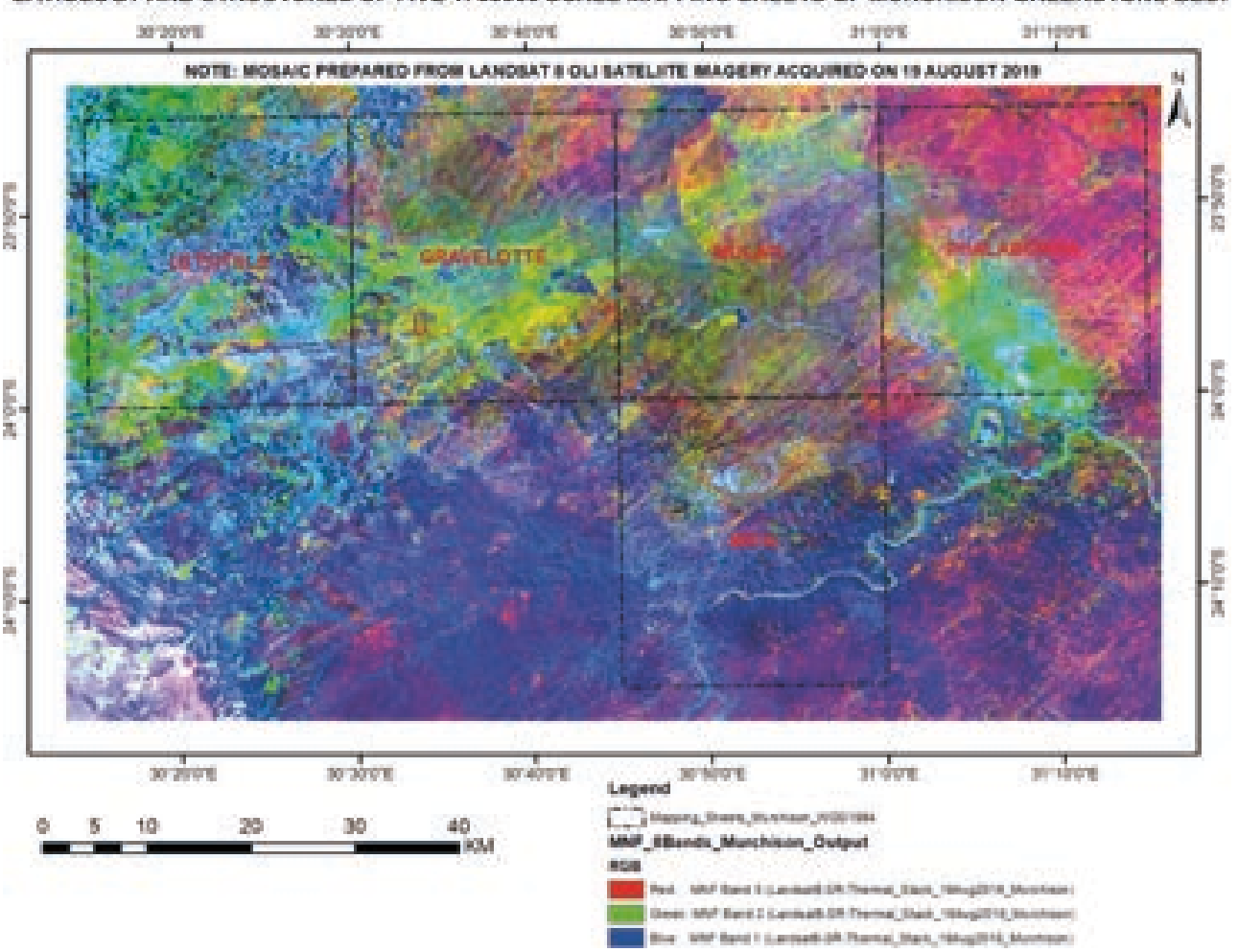

Fig. 24. Lithology and structures identifiable from MNF bands of Landsat 8 (RGB: MNF 5-MNF 2-MNF 1) covering Murchison Greenstone Belt
IRON ONIDES AND CLAY MINERALS OF FIVE 1:60,000 SCALE MAPPING SHEETS OF MURCHISON GREENSTONE BELT

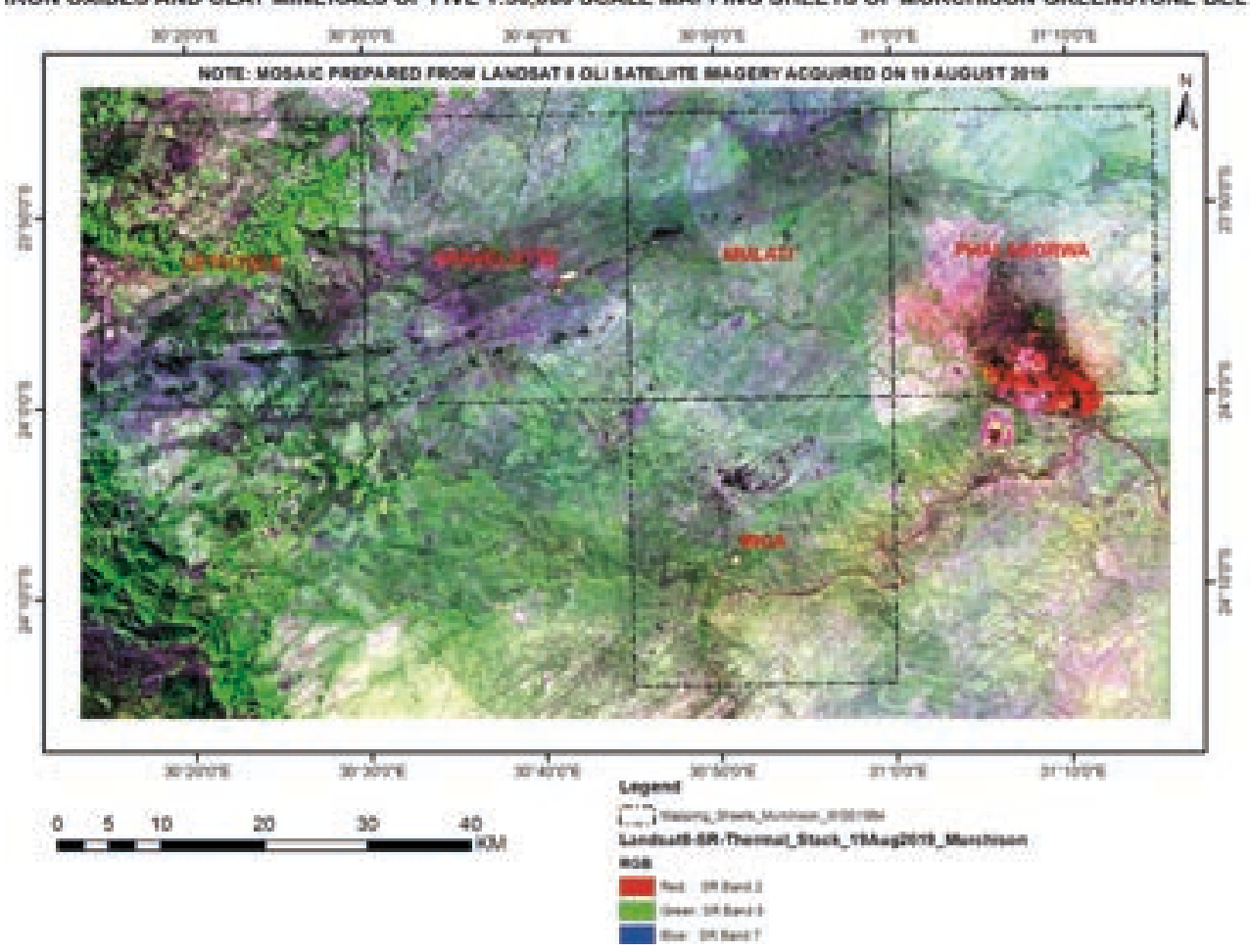

Fig. 25. Iron oxides and clay minerals identifiable from Landsat 8 data using FCC of RGB: B2-B5-B7 covering Murchison Greenstone Belt

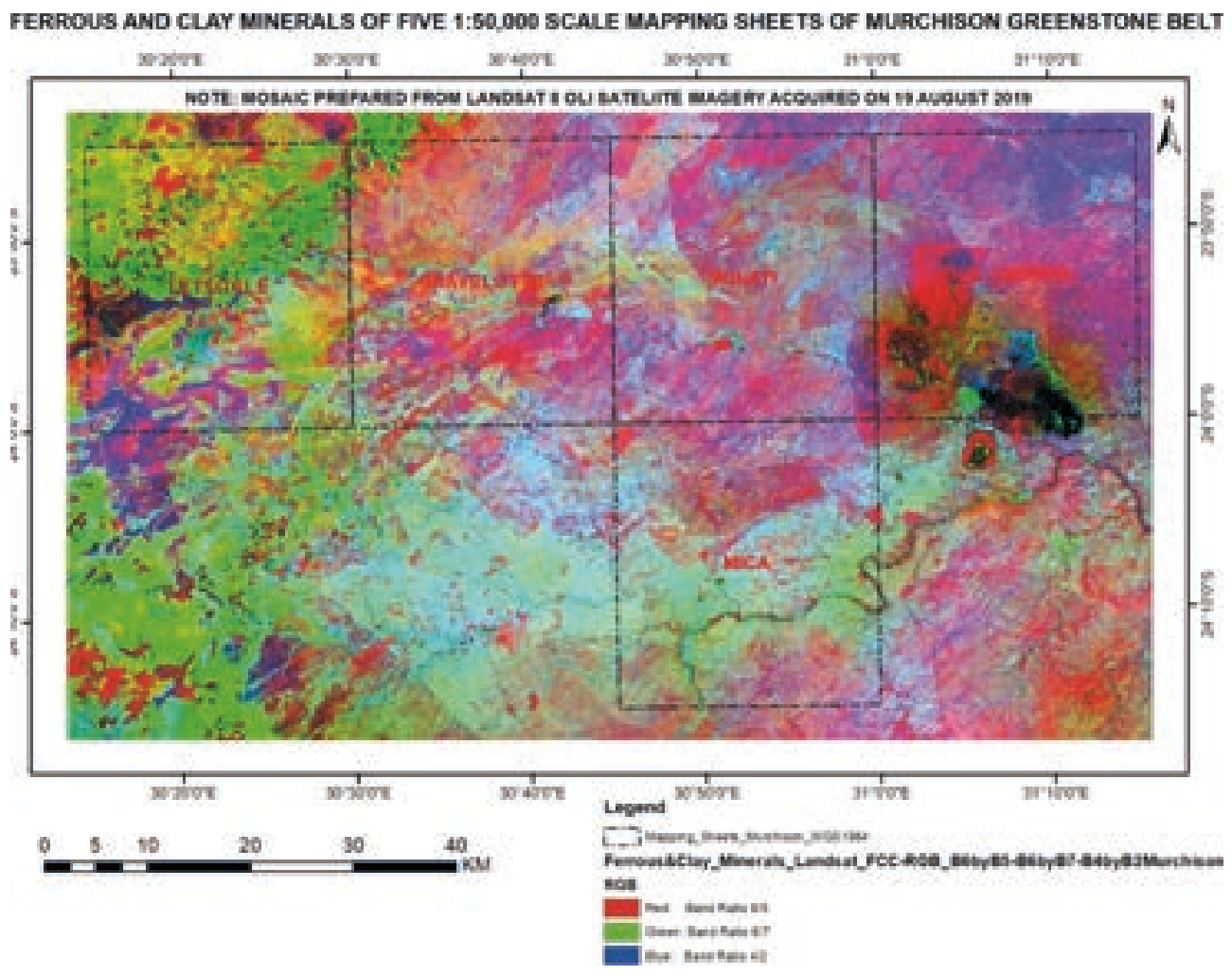

Fig. 26. Ferrous and clay minerals identifiable from Landsat 8 data using FCC of RGB: B6/B5-B6/B7-B4/B2 covering Murchison Greenstone Belt 
Figures 20-26 (on the interleaf) show the selected FCCs generated using Landsat 8 data products enabling discrimination of geological features for mapping purpose. The FCC made from the thermal band 11 and SWIR bands 6 and 7 (Fig. 20) clearly depicts the lithological differences with different shades (blue regions are granitic regions whereas the brown and orange shades are of mafic and ultramafic rocks).

PAN sharpening is a process or technique whereby the multispectral (MS) bands are sharpened for spatial resolution enhancement by means of a panchromatic (PAN) image of higher resolution [23]. The attempt made for PAN sharpening using the $30 \mathrm{~m}$ MS bands (bands 3, 4 and 5) of Landsat 8 with its PAN band of $15 \mathrm{~m}$ (band 8) yielded a FCC that showed more distinct boundaries of the lithological units of the Murchison greenstone belt region and structural features (Fig. 21).

Incorporation of slope in degrees as a band while making FCCs using suitable bands of Landsat 8 yielded products that aid greatly in identifying the outcrops for geological mapping purposes. Figure 22 is an example product obtained from this analysis that helped in identifying the major outcrops and hills of the study area along with distinct boundaries of the green belt region (mafic and ultramafic rocks). In Figure 22 (RGB: B7/B6-B5-Slope), the purple regions are of higher elevations (ridges); the brownish and orange shaded areas are of mafic and ultra-mafic rocks; green shaded regions contain mainly gneissic or granitic rocks. Figure 23 (RGB: B5-B3-B2) shows lithology and structures distinctly. In this figure, the mafic and ultramafic rocks of the study area shown distinctly as purple shades whereas the granitic rocks are represented by the light shades or white patches. The areas of tonalite and granodiorite appear as brown shades. Figure 24 is a product of minimum noise fraction (MNF) analysis done using VNIR and SWIR bands of Landsat 8 . The FCC made using the MNF bands 5, 2 and 3 (Fig. 24) show demarcation of more lithological units with different colour shades due to variation in the minerals or rocks present.

The iron oxides identifiable in the greenstone belt region (mafic and ultramafic volcanic rocks, quartz-feldspar porphyry and quartz-mica schist) and appears as purple shades in Figure 25. The location of ferrous and clay minerals (red and blue shades) identifiable from Landsat 8 data using FCC of RGB: B6/B5-B6/B7-B4/B2 is shown in Figure 26. The red and blue shaded regions in Figure 26 are of mainly weathered portions of mafic and ultramafic volcanic rocks, chlorite schist, quartzite, gritstone, porphyritic tuff, banded iron-formation, siltstone, shale etc. and a few patches of tonalite and granodiorite (seen in the south-eastern part).

The six FCCs made from the following ASTER bands and band ratio combinations in RGB: B4/B7-B4/B3-B2/B1, B4/B7-B4/B1-B2/B3xB4/B3, B6-B3-B1, B4-B3-B1, B6-B2-B1 (Fig. 17), B4-B6-B4/B6 and ten FCCs made from Landsat bands and band ratio combinations in RGB: PAN-sharpened B6-B4-B2 (Fig. 21), B7/B6-B5-Slope (Fig. 22) and B5-B7-Slope, B10-B7-B6, B10-B6-B7, B4/B2-B6/B7-B10, B7-B5-B2, B2-B5-B7, B5-B3-B2 (Fig. 23) and MNF5-MNF2-MNF1 (Fig. 24) from VNIR and SWIR bands, were found to be highly useful in discriminating geology (lithological units), structural features and protruded outcrops including dykes. 


\section{Conclusions}

Recent Landsat 8 satellite image scenes acquired on 19 August 2019 and ASTER image scenes acquired on 5 September 2005, 21 September 2005 and 29 June 2006 that covered the Murchison Greenstone Belt were analysed successfully using geoinformatics software ENVI and SNAP and produced 16 useful image layers from ASTER data and 26 layers from Landsat 8 data that could aid in geological mapping in five mapping sheets (Letsitele, Gravelotte, Mulati, Mica and Phalaborwa) on 1:50,000 scale. The image layers produced as band ratios and colour composites are suitable for geological mapping (for discriminating geology/lithology, structural features and lineaments, alteration and iron oxides, land/water, surface features, vegetation cover and healthy vegetation etc.). The shaded relief made in RGB: 240-0-120 degrees derived from DEM also will enable the delineation of lineaments, dykes, some outcrops and drainage networks.

ASTER FCCs made in RGB: B4/B7-B4/B3-B2/B1, B4/B7-B4/B1-B2/B3xB4/B3, B6-B3-B1, B4-B3-B1, B6-B2-B1, B4-B6-B4/B6 and Landsat FCCs made in RGB: B10-B7-BB6, B10-B6-B7, B4/B2-B6/B7-B10, B7-B5-B2, B2-B5-B7, B5-B3-B2, MNF5-MNF2-MNF1 from VNIR and SWIR bands, PAN-sharpened B6-B4-B2, B7/B6-B5-Slope and B5-B7-Slope are highly useful in discriminating geology (lithological units), structural features and protruded outcrops including dykes that are not so visible in a true colour image of the same resolution. These images shown in this study would allow easy display in a GIS (e.g. ArcGIS) by the mapping geologists. This study could illustrate the usefulness of remote sensing data processing and analysis to aid in geological mapping using freely available ASTER and Landsat 8 data. The quality of the information extracted from the described analysis depends on the inherent quality of the datasets used in this analysis.

\section{Acknowledgments}

The author would like to register his sincere thanks to the Council for Geoscience geological mapping team for providing an opportunity to undertake this study. The author would like to thank the NASA Earthdata for providing ASTER and Landsat 8 data used in this study.

\section{References}

[1] Pournamdari M., Hashim M., Pour A.: Application of ASTER and Landsat TM Data for Geological Mapping of Esfandagheh Ophiolite Complex, Southern Iran. Resource Geology, vol. 64, 2014, pp. 233-246. https://doi.org/10.1111/rge.12038.

[2] Amer R., Kusky T., Ghulam A.: Lithological mapping in the Central Eastern Desert of Egypt using ASTER data. Journal of African Earth Sciences, vol. 56(2-3), 2010, pp. 75-82. https://doi.org/10.1016/j.jafrearsci.2009.06.004. 
[3] Gannouni S., Gabtni H.: Structural Interpretation of Lineaments by Satellite Image Processing (Landsat TM) in the Region of Zahret Medien (Northern Tunisia). Journal of Geographic Information System, vol. 7(2), 2015, pp. 119-127. https://doi.org/10.4236/jgis.2015.72011.

[4] Mohammadizad R., Arfania R.: Advanced investigation of remote sensing to geological mapping of Zefreh region in central Iran. Open Journal of Geology, vol. 7(10), 2017, pp. 1509-1529. https://doi.org/10.4236/ojg.2017.710101.

[5] Mwaniki M.W., Moeller M.S., Schellmann G.: A comparison of Landsat 8 (OLI) and Landsat 7 (ETM+) in mapping geology and visualising lineaments: A case study of central region Kenya. International Archives of the Photogrammetry, Remote Sensing and Spatial Information Sciences, vol. XL-7/W3, 2015, pp. 897-903. https://doi.org/10.5194/isprsarchives-XL-7-W3-897-2015.

[6] Abdelaziz R., El-Rahman Y.A., Wilhelm S.: Landsat-8 data for chromite prospecting in the Logar Massif, Afghanistan. Heliyon, vol. 4(2), 2018, pp. 1-18. https://doi.org/10.1016/j.heliyon.2018.e00542.

[7] Amusuk D.J., Hashim M., Pour A.B., Musa S.I.: Utilization of Landsat-8 data for lithological mapping of basement rocks of Plateau State North Central Nigeria. International Archives of the Photogrammetry, Remote Sensing and Spatial Information Sciences, vol. XLII-4/W1, 2016, pp. 335-337. https://doi.org/10.5194/isprs-archives-XLII-4-W1-335-2016.

[8] Ourhzif Z., Algouti A., Algouti A., Hadach F.: Lithological mapping using Landsat8 OLI and ASTER multispectral data in Imini-Ounilla district South High Atlas of Marrakech. International Archives of the Photogrammetry, Remote Sensing and Spatial Information Sciences, vol. XLII-2/W132019, pp. 1255-1262. https://doi.org/10.5194/isprs-archives-XLII-2-W13-1255-2019.

[9] Banerjee K., Jain M.K., Panda S., Jeyaseelan A.T.: Landsat 8 OLI data for identification of hydrothermal alteration zone in Singhbhum Shear Zone using successive band depth difference technique - a new image processing approach. Current Science, vol. 116(10), 2019, pp. 1639-1647. https://www.currentscience.ac.in/ Volumes/116/10/1639.pdf [access: 12.06.2020].

[10] Prasath L.R., Kusuma K.N.: Lithological mapping using Landsat 8 OLI and ASTER TIR multispectral data: A comparative study. International Journal of Advanced Remote Sensing and GIS, vol. 7(1), 2018, pp. 2728-2745. https://doi.org/10.23953/cloud.ijarsg.369.

[11] Shimoda H., Kimura T.: Missions and Sensors. [in:] Shunlin Liang (ed.), Comprehensive Remote Sensing, Elsevier, 2018, p. 3134.

[12] Westen C.J. van: Geo-information tools for landslide risk assessment: an overview of recent developments. [in:] Lacerda W., Erlich M., Fontoura S.A.B., Sayao A.S.F. (eds.), Landslides: Evaluation and Stabilization, CRC Press, 2004, pp. 39-56.

[13] Buis A.: NASA, Japan Make ASTER Earth Data Available at No Cost. NASA Jet Propulsion Laboratory, April 1, 2016. https://www.jpl.nasa.gov/news/ news.php?feature $=6253$ [access: 26.02 .2020 ]. 
[14] USGS (no date): USGS EROS Archive - Landsat Archives - Landsat 8 OLI (Operational Land Imager) and TIRS (Thermal Infrared Sensor) Level-1 Data Products. https://doi.org/10.5066/F71835S6.

[15] ESA-STEP: ESA SNAP Toolbox surpasses 300000 downloads. 2018. http:// step.esa.int/main/esa-snap-toolbox-surpasses-300000-downloads/ [access: 10.09.2019].

[16] ESA-STEP: SNAP. 2018. http://step.esa.int/main/toolboxes/snap/ [access: 10.09.2019].

[17] Data.Gov: ASTER L2 Surface Reflectance VNIR and Crosstalk Corrected SWIR V003. NASA LP DAAC, 2019. https://catalog.data.gov/dataset/aster-12-surface-reflectance-vnir-and-crosstalk-corrected-swir-v003 [access: 29.02.2020].

[18] NASA EarthData: AST_07XT v003 - ASTER L2 Surface Reflectance VNIR and Crosstalk Corrected SWIR. USGS, 2004. https://lpdaac.usgs.gov/products/ ast_07xtv003/ [access: 2.03.2020].

[19] Kalinowski A., Oliver S.: ASTER Mineral Index Processing Manual, Geoscience Australia. 2004. https://www.ga.gov.au/webtemp/image_cache/GA7833.pdf [access: 2.03.2020].

[20] van der Werff H., van der Meer F.: Sentinel-2A MSI and Landsat 8 OLI Provide Data Continuity for Geological Remote Sensing. Remote Sensing, vol. 8(11), 2016, pp. 883 (1-16). https://doi.org/10.3390/rs8110883.

[21] NASA-JPL: ASTER Instrument Characteristics. Jet Propulsion Laboratory, 2004. https://asterweb.jpl.nasa.gov/characteristics.asp [access: 4.03.2020].

[22] Loyd C.: Landsat 8 Bands. NASA Landsat Science, 2013. https://landsat.gsfc. nasa.gov/landsat-8/landsat-8-bands/ [access: 4.03.2020].

[23] Garzelli A., Aiazzi B., Alparone L., Lolli S., Vivone G.: Multispectral Pansharpening with Radiative Transfer-Based Detail-Injection Modeling for Preserving Changes in Vegetation Cover. Remote Sensing, vol. 10(8), 2018, pp. 1308 (1-18). https://doi.org/10.3390/rs10081308.

\section{Przetwarzanie i analiza obrazów zarejestrowanych przez ASTER oraz Landsat 8 w celu wspomagania tworzenia map geologicznych: studium przypadku obszaru Murchison Greenstone Belt, Republika Południowej Afryki}

Streszczenie: W artykule przedstawiono wyniki przetwarzania i analizy obrazów zarejestrowanych przez satelity ASTER oraz Landsat 8. Czynności te wykonane zostały w celu sporządzenia mapy geologicznej dla regionu Murchison Greenstone Belt w prowincji Limpopo, w Afryce Południowej. Zdjęcia wykonane przez ASTER pochodzą z lat 2005 i 2006, natomiast te zarejestrowane przez Landsat 8 z 2019 roku. Analizowane zdjęcia zostały tak dobrane, aby obejmowały 
obszar odpowiadający pięciu arkuszom mapy geologicznej. Eksperymentowano z wykorzystaniem oprogramowania ENVI i SNAP w celu stworzenia obrazów, które byłyby pomocne w zidentyfikowaniu makroskopowych cech skał, ich struktury, linii nieciągłości, przeobrażeń minerałów i tlenku żelaza, linii pomiędzy lądem i woda, cech powierzchni, pokrycia roślinnościa, wegetacji roślin etc. Korzystając z danych DEM, przygotowano obrazy przedstawiające rzeźbę terenu, które pozwoliły na określenie wysokości terenu, niektórych cech strukturalnych i linii szkieletowych. Wszystkie obrazy zostały później wyeksportowane do plików w formatach GeoTiff i Imagine w celu wyświetlenia ich w ArcMap. Obrazy te okazały się przydatne w rozróżnianiu cech geologicznych i konstrukcyjnych oraz wysokości obiektów, w tym wałów, które nie są dobrze widoczne na obrazach w naturalnych kolorach. Badanie to potwierdza przydatność analizy teledetekcyjnej w tworzeniu map geologiczncyh z wykorzystaniem swobodnie dostępnych danych z satelitów ASTER i Landsat 8.

\section{Słowa}

kluczowe: ASTER, Landsat 8, Murchison Greenstone Belt, mapowanie geologiczne 